\title{
Seasonal variability of aerosol optical properties observed by means of a Raman lidar at an EARLINET site over Northeastern Spain
}

\author{
M. Sicard ${ }^{1}$, F. Rocadenbosch ${ }^{1}$, M. N. M. Reba ${ }^{1}$, A. Comerón ${ }^{2}$, S. Tomás ${ }^{1}$, D. García-Vízcaino ${ }^{2}$, O. Batet ${ }^{2}$, R. Barrios ${ }^{2}$, \\ D. Kumar ${ }^{2}$, and J. M. Baldasano ${ }^{3,4}$ \\ ${ }^{1}$ Dept. of Signal Theory and Communications, Remote Sensing Lab., Universitat Politècnica de Catalunya/Institut d'Estudis \\ Espacials de Catalunya, Barcelona, Spain \\ ${ }^{2}$ Dept. of Signal Theory and Communications, Remote Sensing Lab., Universitat Politècnica de Catalunya, Barcelona, Spain \\ ${ }^{3}$ Earth Sciences Department, Barcelona Supercomputing Center, Barcelona, Spain \\ ${ }^{4}$ Environmental Modeling Laboratory, Universitat Politècnica de Catalunya, Barcelona, Spain
}

Received: 4 May 2010 - Published in Atmos. Chem. Phys. Discuss.: 8 June 2010

Revised: 10 November 2010 - Accepted: 13 December 2010 - Published: 11 January 2011

\begin{abstract}
The annual and seasonal variability of aerosol optical properties observed by means of a Raman lidar over Northeastern Spain has been assessed. The lidar representativeness has first been checked against sun-photometer measurements in terms of aerosol optical thickness. Then the annual cycle and the seasonal variability of the planetary boundary layer aerosol optical thickness and its fraction compared to the columnar optical thickness, the lidar ratio, the backscatter-related Ångström exponent and the planetary boundary layer height are analyzed and discussed. Winter and summer mean profiles of extinction, backscatter and lidar ratio retrieved with the Raman algorithm are presented. The analysis shows the impact of most of the natural events (Saharan dust intrusions, wildfires, etc.) and meteorological situations (summer anticyclonic situation, the formation of the Iberian thermal low, winter long-range transport from North Europe and/or North America, re-circulation flows, etc.) occurring in the Barcelona area. A detailed study of a special event including a combined intrusion of Saharan dust and biomass-burning particles proves the suitability of combining the retrieval of aerosol optical properties from Raman and pure elastic lidar measurements to discriminate spatially different types of aerosols and to follow their spatial and temporal evolution.
\end{abstract}

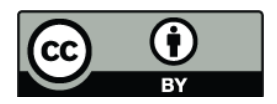

Correspondence to: M. Sicard (msicard@tsc.upc.edu)

\section{Introduction}

Atmospheric aerosols that originate from both natural and anthropogenic activities play a major role in local and global climate and weather changes. Aerosols significantly affect the Earth radiative budget when they interact with the solar radiation and the Earth's long-wave radiation. To this extent, the Intergovernmental Panel on Climate Change (IPPC) has stated that the aerosols considerably contribute to the uncertainty associated to the future global climate predictions (Forster et al., 2007). The assessment of their impact on the Earth radiative budget has been discussed for years and eventually requires an ever increasing knowledge of their characteristics and of their temporal and spatial distribution.

In Europe, one of the most serious air quality problems is related to particulate matter (PM) with a diameter under $10 \mu \mathrm{m}\left(\mathrm{PM}_{10}\right)$ (De Leeuw et al., 2001). The objectives proposed by the European Union (EU) related to air quality for year 2010 are more difficultly reached in Southern Europe around the Mediterranean Basin than in Northern Europe. Over Eastern Spain, Rodríguez (2002a) yielded annual mean $\mathrm{PM}_{10}$ levels of $17-20,30-45$ and $45-60 \mu \mathrm{g} \mathrm{m}^{-3}$ at rural, urban and industrial sites, respectively, outlining that even $\mathrm{PM}_{10}$ rural levels were only slightly lower than the $2010 \mathrm{EU}$ $\mathrm{PM}_{10}$ objectives for urban and industrial sites. Several reasons explain such behaviors in the Western Mediterranean Basin (WMB).

The WMB is surrounded by high coastal mountains and in summer it becomes isolated from the traveling lows and their frontal systems, which affect the weather at higher latitudes. The meteorology is highly influenced by the Azores highpressure system, which is located over the Atlantic Ocean

Published by Copernicus Publications on behalf of the European Geosciences Union. 
and which intensifies during the warm season inducing very weak pressure gradient conditions all over the region. Precipitations are poor and irregular. Under weak synoptic forcing, air-mass coastal re-circulations become "large natural photochemical reactors" where secondary aerosols are formed in large quantities (Beck et al., 1999). In addition, the contribution of mineral aerosols is very high due to the poor vegetable soil coverage and the frequent occurrence of Saharan dust events (Rodríguez et al., 2001). Re-suspension of loose material on the road surface may also significantly contribute to $\mathrm{PM}_{10}$ levels in the dry season. According to Rodríguez et al. (2002a), at rural sites over Eastern Spain, the highest PM events are reported during Saharan dust events (daily concentrations $40-60 \mu \mathrm{g} \mathrm{m}^{-3}$ ) and the second highest PM events (daily concentrations $20-45 \mu \mathrm{g} \mathrm{m}^{-3}$ ) are reported during ozone-related pollution episodes. The relief of the continental areas in the WMB contributes to the complexity of the dispersion of the aerosols in the region. The presence of highly urbanized coastlines poses significant problems for understanding, monitoring and forecasting the transport and dispersion of the aerosols in the atmosphere which have been the subject of many studies (Millán et al., 1992, 1997; Jiménez et al., 2006).

In Northeastern Spain, Barcelona and its surroundings are one of the largest urban coastal areas of the WMB. Due to the reasons mentioned above, the variability in concentration, size, shape, composition and vertical distribution of the atmospheric aerosols in this area is very high. Consequently, global aerosol models and radiative transfer models still suffer from large uncertainties when applied to this region. Long-term observations of aerosol vertical profiles are a key point to reduce them. The lidar technique provides vertical profiles of the aerosol optical properties with a high vertical and temporal resolution, in particular the Raman technique is the most suitable technique for ground-based aerosol study because it allows to characterize atmospheric aerosols in terms of vertical profiles of extinction and backscatter coefficients without any assumptions on the aerosol type and composition (Ansmann et al., 1992).

The European Aerosol Research Lidar Network (EARLINET) established since 2000 provides a comprehensive, quantitative, and statistically significant database of the atmospheric aerosol vertical distribution at a continental scale using a network of advanced lidar stations (Bösenberg et al., 2002). Since March 2006 the network is supported by the EU through the project EARLINET-ASOS (European Aerosol Research Lidar Network to establish an aerosol climatology - Advanced Sustainable Observation System) (Pappalardo et al., 2007). In the framework of this project the Barcelona lidar station from the Remote Sensing Laboratory (RSLAB) of the Universitat Politècnica de Catalunya (UPC) has been performing observations of atmospheric aerosols on a regular basis. Thus, this paper deals with the climatology of the aerosol optical properties such as optical thickness, lidar ratio, Ångström exponent and planetary boundary layer height measured by lidar in Barcelona over three full years 2007 2009. Section 2 presents the instrumentation and methodology. In order to demonstrate the representativeness of the lidar measurements the latter are compared on a statistical basis with sun-photometer data in terms of aerosol optical thickness. This validation is presented in Sect. 3.1. Next in Sect. 3.2, the climatology of the lidar ratio, Angström exponent and planetary boundary layer height is presented. Seasonal mean vertical profiles of lidar ratio are discussed in Sect. 3.3 and finally a special emphasis is made on special events in Sect. 3.4.

\section{Instrumentation and methodology}

\subsection{Sun-sky photometer}

The columnar aerosol optical thickness (AOT) was measured by a CIMEL sun-sky photometer, which is part of the Aerosol Robotic Network (AERONET) (Holben et al., 1998). The sun-photometer is located on the roof of one of the buildings of the UPC in Barcelona, Spain, in an urban area $\left(41.384^{\circ} \mathrm{N}, 2.11^{\circ} \mathrm{E}, 125 \mathrm{~m}\right.$ a.s.l.). The instrument makes direct sun measurements with a $1.2-^{\circ}$ field of view, in the spectral bands of 440, 675, 870, 940 and $1020 \mathrm{~nm}$. Taking into account all the information about the instrument precision, calibration precision and data accuracy (Holben et al., 1998), the estimated accuracy of the AOT measurements to be presented next is about \pm 0.02 for the level 2 data (cloudscreened and quality-assured) which are used in this paper. In this work and for the period between 1 January 2007-31 December 2009, two types of values have been used: punctual values for constraining the lidar inversion, the temporal coincidence between the lidar and the sun-photometer measurement being less than $\pm 30 \mathrm{~min}$, and daily averaged values for the AOT seasonal variability analysis (Sect. 3.1).

The AOT at the lidar wavelengths of 532 and $1064 \mathrm{~nm}$ were computed from the sun-photometer AOT at 440 and $1020 \mathrm{~nm}$, respectively. Both AOTs were corrected for the AOT spectral dependence using the Ångström exponent $\left(\mathrm{AE}_{\mathrm{sp}}\right)$ calculated between 440 and $675 \mathrm{~nm}$ and between 870 and $1020 \mathrm{~nm}$, respectively. In both regions the sunphotometer $\mathrm{AE}_{\mathrm{sp}}$ was calculated as follows:

$\mathrm{AE}_{\mathrm{sp}}=-\frac{\ln \left[\frac{\mathrm{AOT}\left(\lambda_{1}\right)}{\operatorname{AOT}\left(\lambda_{2}\right)}\right]}{\ln \left[\frac{\lambda_{1}}{\lambda_{2}}\right]}$

where $\left(\lambda_{1}, \lambda_{2}\right)$ are the pairs $(440,675 \mathrm{~nm})$ and $(870$, $1020 \mathrm{~nm})$.

\subsection{Barcelona lidar}

The lidar group from the RSLAB has developed in 2002 a transportable and steerable Raman lidar system (Rocadenbosch et al., 2002) which has been operated since then. The 
lidar is located on the roof of one of the buildings of the Department of Signal Theory and Communications $\left(41.39^{\circ} \mathrm{N}\right.$, $2.11^{\circ} \mathrm{E}, 115 \mathrm{~m}$ a.s.1.) of the UPC at approximately $600 \mathrm{~m}$ Northwest of the CIMEL sun-photometer. The present lidar system is based on a $\mathrm{Nd}$ :YAG laser operating at the fundamental and second harmonic wavelengths of 1064 and $532 \mathrm{~nm}$, respectively, and transmitting pulses of $160-\mathrm{mJ}$ energy at a repetition rate of $20 \mathrm{~Hz}$. The receiver consists of a Cassegrain telescope in a biaxial arrangement. The received radiation is separated into three channels using dichroic filters. Interference filters are used to spectrally select the elastic backscattered radiation at 1064 and $532 \mathrm{~nm}$, and the Nitrogen Raman-shifted backscattered radiation at $607 \mathrm{~nm}$. Photomultiplier tubes are used at 532 and $607 \mathrm{~nm}$ while an avalanche photodiode is used at $1064 \mathrm{~nm}$. The signals at 532 and $1064 \mathrm{~nm}$ are sampled in an analog mode while at $607 \mathrm{~nm}$ both analog and photon counting signals are simultaneously recorded. The usual time resolution of the profiles is $1 \mathrm{~min}$. Range-square-corrected signal profiles are formed following a two step procedure. First, and for all three wavelengths, a background lidar calibration profile (which is usually not flat for it contains distortions due to the detector behaviour operating in analog mode) is subtracted to the measured raw lidar profiles. The background calibration profile is recorded prior to the measurement with the telescope aperture covered. Second, and only for $532 \mathrm{~nm}$, once a flat-background raw lidar profile is obtained from the previous step a leastsquares Rayleigh fit procedure is used to estimate (and subtract) the residual background-level offset. In the Rayleighfit method each individual lidar profile, i.e. every minute, is compared with that from a purely molecular atmosphere so that a least-squares procedure performs a fit over a purely molecular reference range (Reba et al., 2010b). From this comparison the background offset can be estimated. At 1064 and $607 \mathrm{~nm}$ the residual background-level offset is calculated as the average of the lidar returned power between the ranges $20-24 \mathrm{~km}$. During daytime, the aerosol optical coefficient profiles (backscatter and extinction) were retrieved by means of the two-component elastic lidar inversion algorithm (Fernald, 1984; Sasano and Nakane, 1984; Klett, 1985) constrained with the sun-photometer-derived AOT (Landulfo et al., 2003; Reba et al., 2010a). The method is based on an iterative lidar ratio (LR) search by comparing the lidar AOT with that from the sun-photometer using a bisection-search method and a lidar ratio termination error goal, $\varepsilon$, set by the user (Reba et al., 2010a). Here $\varepsilon$ was fixed to $1 \mathrm{sr}$.

Most of the nighttime measurements at $532 \mathrm{~nm}$ were inverted with the Raman lidar inversion algorithm (Ansmann et al., 1990). In some of the nighttime measurements acquired at sunset the Raman channel was not recorded and therefore the inversions at $532 \mathrm{~nm}$ were made with the two-component elastic lidar algorithm using a constant LR of 50 sr. All nighttime measurements at $1064 \mathrm{~nm}$ were inverted in the same way with the two-component elastic lidar algorithm.
The daytime lidar-derived AOT was measured by integrating the aerosol extinction coefficient profile from the minimum height of confidence namely the height where the overlap factor reaches 1, usually between 400 and $500 \mathrm{~m}$ a.g.l., and up to the free troposphere. For the first part of the PBL, which is not "seen" by the lidar because of its incomplete overlap factor, the extinction was assumed to be a flat extrapolation of the extinction profile at the range of full overlap (Reba et al., 2010a).

The retrieval of the planetary boundary layer (PBL) height was made using the gradient method (Sicard et al., 2006). All profiles were visually inspected and the resulting PBL height was cross-compared with the previous and the following height in order to guarantee temporal coherency in its evolution. The PBL heights retrieved from both the 532- and the 1064-nm lidar signals give exactly the same results.

Since March 2006, the UPC lidar is involved in regular measurements scheduled within EARLINET-ASOS (Pappalardo et al., 2007). Three measurements a week are scheduled: on Monday at 14:00 LST (local solar time) $\pm 1 \mathrm{~h}$ and at sunset $-2 h+3 h$ and on Thursday at sunset $-2 h+3 h$. All those measurements were processed as daytime measurements except for some sunset measurements which were performed after dark (most of them in winter time). When the Raman channel was recorded, those sunset measurements were processed with the Raman algorithm.

Also in the framework of EARLINET-ASOS a Saharan dust alert system has been established in order to perform ad-hoc measurements in case of intrusions of desert particles over the European continent (Pappalardo et al., 2009). Dust forecasts are distributed to all EARLINET stations by the National Technical University of Athens (NTUA) group, which coordinates the monitoring of the dust outbreaks within the network. The dust forecast is based on the operational outputs (aerosol dust load) of the BSC-DREAM8b (Nickovic et al., 2001; Pérez et al., 2006a, b) (Dust Regional Atmospheric Model, operated in the past in Malta at the Centre on Insular Coastal Dynamics and now at the Barcelona Supercomputing Center, Barcelona, Spain: http: //www.bsc.es/projects/earthscience/DREAM/) and the SKIRON (Kallos et al., 1997) (operated at NTUA, Greece: http://forecast.uoa.gr) models. Alerts are issued 24 to $36 \mathrm{~h}$ prior to the arrival of dust aerosols over the EARLINET sites, so that each participating station can arrange special measurements. For both measurement types (regular and Saharan dust alerts) the typical averaging time is $30 \mathrm{~min}$.

As a member of EARLINET, the UPC lidar is also involved since June 2006 in the CAL/VAL exercise of the CALIOP (Cloud-Aerosol Lidar with Orthogonal Polarization) lidar flying on board CALIPSO (Cloud-Aerosol Lidar and Infrared Pathfinder Satellite Observations) (Winker et al., 2007). CALIOP is an elastic backscatter lidar that provides vertical profiles of aerosol and cloud backscatter coefficients at 532 and $1064 \mathrm{~nm}$ and depolarization ratio profiles at $532 \mathrm{~nm}$. 150-min measurements are performed each 
Table 1. Number of measurements performed and inverted satisfactorily during the period 2007-2009, T, D and N indicate, respectively, Total, Day and Night.

\begin{tabular}{lrrr|rrr|rrr|rrr|rr|rr}
\hline & \multicolumn{3}{c}{2007} & \multicolumn{3}{c}{2008} & \multicolumn{3}{c}{2009} & \multicolumn{1}{c}{$2007-2009$} \\
\hline & $\mathrm{T}$ & $\mathrm{D}$ & $\mathrm{N}$ & $\mathrm{T}$ & $\mathrm{D}$ & $\mathrm{N}$ & $\mathrm{T}$ & $\mathrm{D}$ & $\mathrm{N}$ & $\mathrm{T}$ & $\mathrm{D}$ & $\mathrm{N}$ \\
\hline Total & 56 & 50 & 6 & 32 & 21 & 11 & 63 & 35 & 28 & 151 & & 106 & & 45 \\
Regular & 34 & 34 & 0 & 15 & 12 & 3 & 35 & 22 & 13 & 84 & $56 \%$ & 68 & $64 \%$ & 16 & $36 \%$ \\
CALIPSO & 14 & 8 & 6 & 12 & 5 & 7 & 21 & 9 & 12 & 47 & $31 \%$ & 22 & $21 \%$ & 25 & $56 \%$ \\
Dust & 8 & 8 & 0 & 5 & 4 & 1 & 7 & 4 & 3 & 20 & $13 \%$ & 16 & $15 \%$ & 4 & $9 \%$ \\
\hline
\end{tabular}

Table 2. Annual, winter and summer means and errorbars (computed with the ML estimation) of the columnar AOT, the PBL AOT, the ratio $\frac{\mathrm{AOT}_{\mathrm{PBL}}}{\mathrm{AOT}_{\text {column }}}$, the lidar ratio, the backscatter-related Ångström exponent and the PBL height.

\begin{tabular}{|c|c|c|c|c|c|c|c|c|c|c|c|c|c|c|c|c|}
\hline & \multicolumn{4}{|c|}{$\mathrm{AOT}_{\text {column }}$} & \multicolumn{4}{|c|}{ AOT $_{\mathrm{PBL}}$} & \multicolumn{2}{|c|}{$\mathrm{AOT}_{\mathrm{PBL}} / \mathrm{AOT}_{\text {column }}(\%)$} & \multicolumn{2}{|c|}{ Lidar ratio (sr) } & \multicolumn{2}{|c|}{ Ångström exponent } & \multicolumn{2}{|c|}{ PBL Height (m) } \\
\hline Wavelength $(\mathrm{nm})$ & & 32 & & 64 & & 32 & & 64 & 532 & 1064 & 532 & 1064 & & & & \\
\hline Year & 0.14 & \pm 0.02 & 0.07 & \pm 0.01 & 0.08 & \pm 0.01 & 0.03 & \pm 0.01 & 57 & 43 & 56 & 37 & 0.91 & \pm 0.02 & 1257 & \pm 27 \\
\hline Winter & 0,10 & \pm 0.03 & 0.05 & \pm 0.01 & 0.08 & \pm 0.02 & 0.03 & \pm 0.01 & 80 & 60 & 51 & 33 & 1.00 & \pm 0.02 & 1035 & \pm 44 \\
\hline Summer & 0.20 & \pm 0.03 & 0,09 & \pm 0.02 & 0.07 & \pm 0.02 & 0.04 & \pm 0.02 & 35 & 44 & 60 & 42 & 0.82 & \pm 0.02 & 1388 & \pm 33 \\
\hline
\end{tabular}

time CALIPSO overpasses the UPC site within a maximum distance of $100 \mathrm{~km}$ and $2 \mathrm{~h}$ (Case 1) or when the nearest EARLINET station (Case 2) or the nearest multi-wavelength EARLINET station (Case 3) performs measurements in coincidence with CALIPSO overpasses (Mattis et al., 2007; Pappalardo et al., 2010).

Table 1 shows the number of measurements satisfactorily inverted for each type described above during the period 2007-2009. Those numbers do not reflect the number of measurements performed indeed but the number of quality-assured inversions obtained from the measurements performed. As an example, in the period 20072009, 462 regular measurements were scheduled, 199 (43\%) were performed and out of those 199 measurements 84 $(42 \%)$ inversions were satisfactorily obtained. The reasons for not performing the measurements are the presence of low clouds or rain, technical problems, system upgrading/reparation/maintenance, manpower shortage and field campaigns outside of Barcelona (Reba, 2010b). The inversions were not quality-assured when no sun-photometer AOT was available or when the lidar signal showed too poor quality (presence of an artificial signature due to noise interferences, detector saturation, too low signal-to-noise ratio, etc.). During the same period approximately 20 Saharan dust measurements were inverted satisfactorily and a total of 47 CALIPSO measurements regardless of the Case number were also inverted satisfactorily.

\section{Results and discussion}

The data presented here were obtained in Barcelona, Spain, by both a CIMEL sun-photometer and the UPC lidar over a period of three years between 1 January 2007 and 31 December 2009. A total of 151 lidar inversions are available, 106 during daytime and 45 during nighttime. The daytime measurements are first used to demonstrate the representativeness of the lidar measurements to reliably reproduce the annual evolution of the aerosol optical properties by comparing sunphotometer and lidar AOT on a statistical basis. Once data representativeness is demonstrated, the annual cycle of the lidar ratio, the backscatter-related Ångström exponent and the PBL height are analyzed and discussed, as well as mean vertical profiles of lidar ratio retrieved with the Raman algorithm. Finally, a special event is analysed in Sect. 3.4.

In Sect. 3.1 where the lidar-derived AOT is compared to that of the sun-photometer the monthly mean estimates and their mean errorbar are computed as the arithmetic mean values and the standard deviation, respectively. This way the errorbar gives an estimation of the variability of the single values around the mean value showing the atmospheric variability. In Sect. 3.2, since the single values came with an associated errorbar, the monthly mean estimates and their mean errorbar are computed using the maximum likelihood (ML) estimation described in Appendix A (Eqs. A1 and A2), respectively). This way the monthly mean estimate represents a weighted mean value and its errorbar gives the degree of confidence of that mean value. The variability of the single values around the mean value is shown by means of probability density function plots. The annual and seasonal (winter and summer) mean estimates given in Table 2 were all 


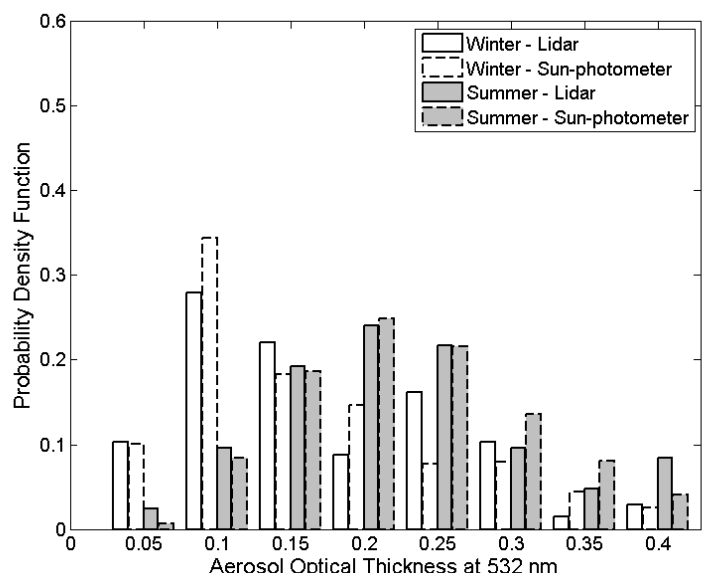

(a)

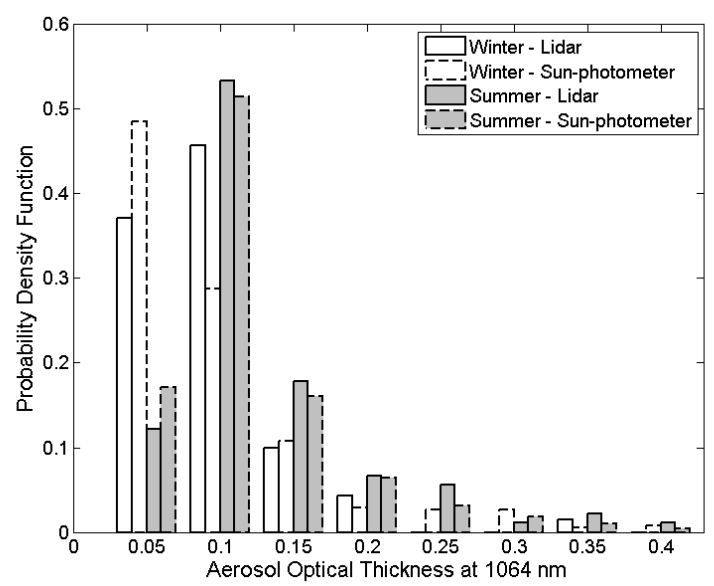

(b)

Fig. 1. Sun-photometer- and lidar-derived AOT probability density function for winter (October-March) and summer (AprilSeptember) (a) at $532 \mathrm{~nm}$ and (b) at $1064 \mathrm{~nm}$.

computed from the monthly mean estimates and their mean errorbar using the ML estimation. In Sect. 3.3 all mean values are computed as the ML estimate (Eq. A1) and their mean errorbar as the standard deviation (Eq. A3) in order to show in the same figure the atmospheric variability.

\subsection{AOT seasonal variability}

Figures 1 and 2 are intended to show on a statistical basis the representativeness of the lidar measurements. This is achieved by comparing the probability density function (PDF) and annual cycle of the AOT retrieved from both the daytime lidar measurements and the daily sunphotometer data. Let's recall that the method used to invert the daytime lidar signals constrains the lidar AOT to that of the sun-photometer in such a way that the daytime lidar measurements eventually represent a small subset of the sun-photometer measurements. Figure 1 shows the sunphotometer- and lidar-derived AOT PDF for winter and sum-

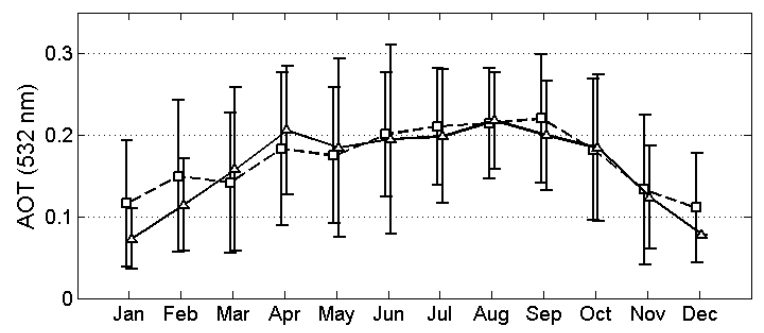

(a)

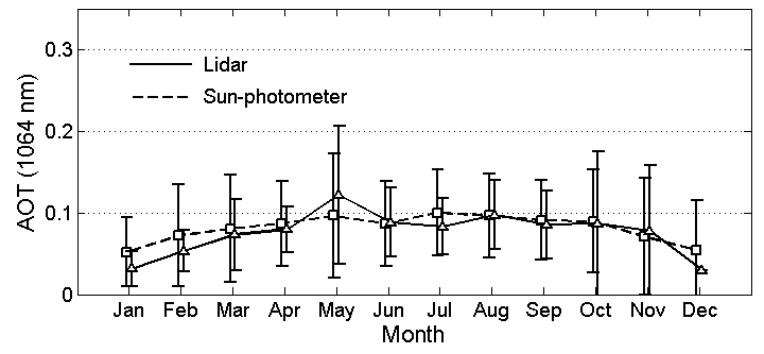

(b)

Fig. 2. Annual cycle of the sun-photometer- and lidar-derived AOT (a) at $532 \mathrm{~nm}$ and (b) at $1064 \mathrm{~nm}$. Lidar data are represented by triangles and solid lines. Sun-photometer data are represented by squares and dashes lines.

mer at 532 and $1064 \mathrm{~nm}$. The AOT range for each bar is 0.05. Winters and summers have been defined from October to March and from April to September, respectively. Even though some AOT values as high as 1 were measured, Fig. 1a, b were intentionally cut at 0.4 below which more than $90 \%$ of AOT values fall. At both wavelengths and during both seasons the from both datasets are quite similar. The agreement between both datasets is remarkably good during summer. Figure $2 \mathrm{a}$ and $\mathrm{b}$ show the annual cycle of both AOTs at 532 and $1064 \mathrm{~nm}$, respectively. The errorbar (showing the atmospheric variability) associated with the monthly mean value is the standard deviation. By using the ML estimation described in Appendix A, annual and seasonal mean values were computed. The lidar-derived annual mean AOT is $0.14 \pm 0.02$ and $0.07 \pm 0.01$ at 532 and $1064 \mathrm{~nm}$, respectively, whereas the winter and summer mean values are $0.10 \pm 0.03$ and $0.20 \pm 0.03$ at $532 \mathrm{~nm}$ and $0.05 \pm 0.01$ and $0.09 \pm 0.02$ at $1064 \mathrm{~nm}$. The differences between winter and summer mean values are mainly due to long-range transport aerosols such as Saharan dust (more frequent in summer than in winter) and biomass burning particles (not present in winter). In both seasons Fig. 1a and b show that a non-negligible number of cases with relatively high AOTs, let's say above 0.3 at $532 \mathrm{~nm}$ and above 0.15 at $1064 \mathrm{~nm}$, are observed. This result evidences the presence of Saharan dust in all seasons. However in winter those episodes with high AOTs do not have a significant impact on the mean seasonal AOT value: even though the cumulative PDFs of high AOTs are relatively high $\left(\mathrm{PDF}\left(\mathrm{AOT}_{532}>0.3\right) \simeq 0.2\right.$ and $\left.\operatorname{PDF}\left(\mathrm{AOT}_{1064}>0.15\right) \simeq 0.25\right)$, the winter mean AOTs are 
low: 0.10 at $532 \mathrm{~nm}$ and 0.05 at $1064 \mathrm{~nm}$. The presence of Saharan dust all year round was expected since during the winter months Saharan dust intrusions (the main contributor to the increase of the mean annual AOT in Northeastern Spain), occur approximately as many times as during July and August (Rodríguez et al., 2001, 2002b; Querol et al., 2002). In the cases of relatively high AOTs the agreement between both datasets is usually not so good. It emerges that the PDF of the AOT in summer follows a Gaussian-like distribution centered on $\sim 0.2$ and $\sim 0.1$ at 532 and $1064 \mathrm{~nm}$, respectively. Both Fig. 2a and b show qualitatively and quantitatively a good agreement between both datasets. In spite of a statistically lower number of lidar measurements the variability of the monthly AOTs (given by the errorbar) is similar for both datasets. This result reinforces the representativeness of the lidar measurements since it indicates that the monthly set of lidar-derived AOTs span a similar range of values to that of the sun-photometer-derived. The difference between sun-photometer and lidar seasonal mean AOTs is lower than 0.03 at $532 \mathrm{~nm}$ and lower than 0.02 at $1064 \mathrm{~nm}$ in winter while it is lower than 0.01 at both wavelengths in summer. The agreement between both datasets is relatively good even though some discrepancies are observed in winter. Those discrepancies are visible in Fig. 1b (for AOT values lower than 0.1) and Fig. 2a and b especially in December, January and February. They are due to a lesser number of lidar measurements (which causes the errorbars not to be representative of the statistical sample) due to either bad weather or a lack of sun-photometer measurements, sunset measurements being performed at nighttime during these months of the year. The difference between the monthly AOTS of both datasets at $532 \mathrm{~nm}$ is in average $6.4 \%$ in summer and $19 \%$ in winter (7\% if we exclude the months of December, January and February). At $1064 \mathrm{~nm}$ it is $10.2 \%$ in summer and $22.2 \%$ in winter (7.4\% if we exclude the months of December, January and February). If we exclude those three months one can say that the lidar and the sun-photometer AOT annual cycles agree well and that differences do not exceed $\sim 10 \%$. Finally it is worth noting that the AOT annual variation observed in Barcelona is very similar to that observed in Valencia, situated also on the Mediterranean coast at $300 \mathrm{~km}$ southwest of Barcelona (Estellés et al., 2008). Figure 3 shows the columnar AOT and the AOT inside the PBL, both measured by the lidar. The columnar AOT is the same as the solid line shown in Fig. 2. The PBL AOT was obtained by integrating the extinction profiles from the ground level up to the PBL height (and using the extinction extrapolation discussed in Sect. 2.2). The errorbar (showing the atmospheric variability) associated with the monthly mean value is the standard deviation. Three interesting features stand out of Fig. 3:

- The columnar AOT is always larger than the PBL AOT, which indicates that aerosol layers are detected above the PBL all year round (except in December, January and February where both AOTs are nearly equal). The fact that the PBL AOT does not increase in summer is also partially due to the sea-breeze phenomenon which produces a stronger "clean up" effect in summer than in winter (Santacesaria et al., 1998).

- The PBL AOT is virtually constant all year round. The annual mean value computed with the ML estimation described in Appendix A is around $0.08 \pm 0.01$ at $532 \mathrm{~nm}$ and around $0.03 \pm 0.01$ at $1064 \mathrm{~nm}$, which represents 57 and $43 \%$ of the annual mean columnar AOT, respectively. This is a very interesting result because it shows that no systematic coupling exists between the PBL and the above layers. Note also that most of the standard deviations are 1.5 to 2 times smaller than those of the columnar AOT. Recently Pérez et al. (2008) showed that PM levels in Barcelona do not exhibit a marked seasonal trend. This result is also a motivation to further investigate about the possible relationship between PM levels and the PBL AOT (rather than the columnar AOT).

- During summer the fraction of AOT contained in the PBL is very similar at both wavelengths $(35 \%$ at $532 \mathrm{~nm}$ and $44 \%$ at $1064 \mathrm{~nm}$ ). This emphasizes the impact of long-range transport of aerosols in summer time which are responsible of the AOT increase. The columnar AOT increase observed in summer is therefore due to tropospheric aerosols, among them Saharan dust which is known for being poorly wavelength-dependent.

In a former paper Mattis et al. (2004) found that the annual mean PBL AOT in a continental site represented $78 \%$ of the total AOT at $532 \mathrm{~nm}$. This difference highlights the effects that local phenomena such as the sea-breeze and the Iberian thermal low (not present in a continental site) have on the aerosol vertical dynamics.

All mean values of the lidar-derived parameters are listed in Table 2.

\subsection{Lidar ratio, Ångström exponent and PBL height seasonal variability}

The columnar lidar ratio has been retrieved from the daytime lidar measurements using the two-component elastic lidar algorithm constrained with the sun-photometer-derived AOT (see Sect. 2.2). It is indeed a proxy of the average lidar ratio in the whole atmospheric column (Pelon et al., 2002). Its annual cycle, the PDF at $532 \mathrm{~nm}$ and the PDF at $1064 \mathrm{~nm}$ are shown in Fig. 4a, b and c, respectively. All single values of the lidar ratio came with an errorbar of $\varepsilon=1 \mathrm{sr}$ (see Sect. 2.2 and Reba et al., 2010a). In those conditions the mean errorbar associated to the monthly mean estimates is less than $1 \mathrm{sr}$ when computed with the ML estimation. This errorbar represents the error due to the method only. Because so small values would not be visible in Fig. 4a, the errobars are not represented in that figure. Note that here the estimated accuracy of the sun-photometer AOT measurements, 0.02 , has not 


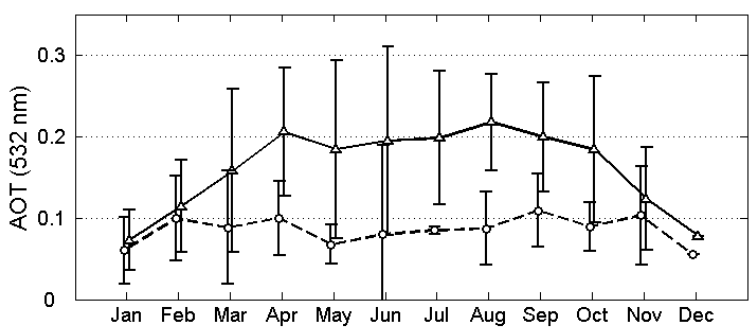

(a)

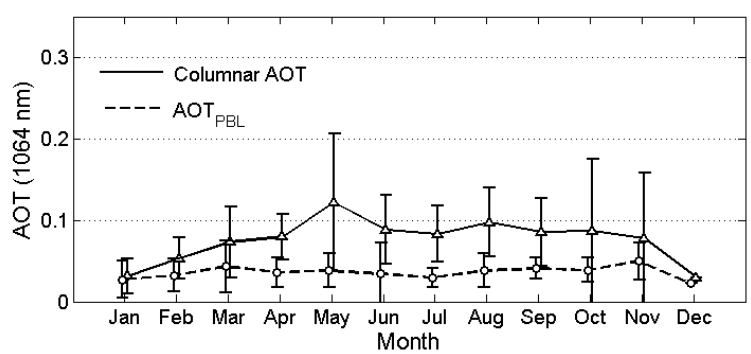

(b)

Fig. 3. Lidar-derived columnar AOT and fraction of the AOT included in the PBL.

been taken into account in the elastic algorithm constrained with the sun-photometer-derived AOT. Both annual cycles of the lidar ratio at $532\left(\mathrm{LR}_{532}\right)$ and $1064 \mathrm{~nm}\left(\mathrm{LR}_{1064}\right)$ are very similar in shape, $\mathrm{LR}_{1064}$ being approximately on average 15 to $20 \mathrm{sr}$ lower than $\mathrm{LR}_{532}$. Since the inversions at both wavelengths were made independently of each other, this result validates somehow the combined method used. By using the ML estimation, winter and summer mean values were computed. At $532 \mathrm{~nm}$ mean values of $51 \mathrm{sr}$ in winter and $60 \mathrm{sr}$ in summer are found, while at $1064 \mathrm{~nm}$ mean values of $33 \mathrm{sr}$ in winter and $42 \mathrm{sr}$ in summer are found (all values have be rounded to the closest integer). The differences observed between both seasons, around $10 \mathrm{sr}$, show that the impact of Saharan dust intrusions is stronger in summer than in winter. The two peaks visible in April and July at $1064 \mathrm{~nm}$ (also visible but less marked at $532 \mathrm{~nm}$ ) correspond to the months with the highest number of Saharan dust intrusions. Independently of the wavelength typical values of lidar ratio for mineral dust range between 50 and $60 \mathrm{sr}$ (De Tomasi et al., 2003; Amiridis et al., 2005; Mona et al., 2006; Papayannis et al., 2008; Tesche et al., 2009). The lower lidar ratio values observed at $1064 \mathrm{~nm}$ prove that background aerosols, mostly formed by urban aerosols in Barcelona, have optical properties highly wavelength-dependent. Figure $4 \mathrm{~b}$ and c show that during winter $\operatorname{PDF}\left(\mathrm{LR}_{532}>60 \mathrm{sr}\right) \simeq 0.35$ and $\operatorname{PDF}\left(\mathrm{LR}_{1064}>60 \mathrm{sr}\right) \simeq 0.2$. If those cases, equivalent to high AOTs, were omitted in the computation of the winter mean values then the mean $\mathrm{LR}_{532}$ and $\mathrm{LR}_{1064}$ due to background aerosols would be found lower than 51 and $33 \mathrm{sr}$, respectively.

Figure 5 shows the annual cycle and the PDF of the backscatter-related Ångström exponent (sometimes called

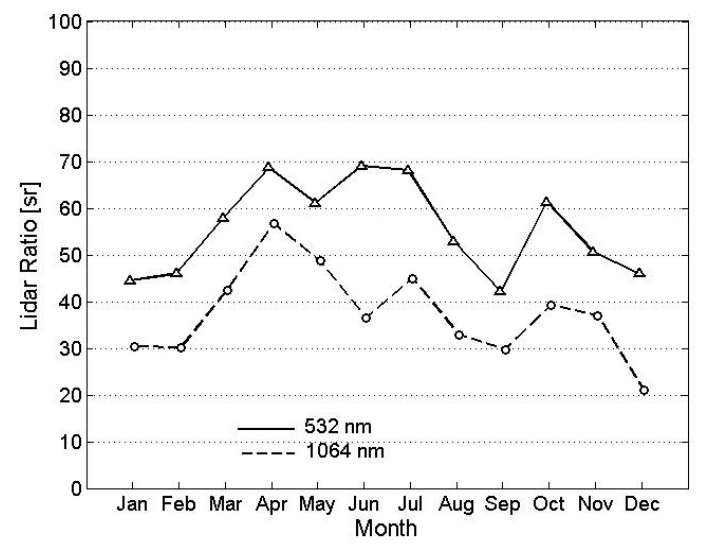

(a)

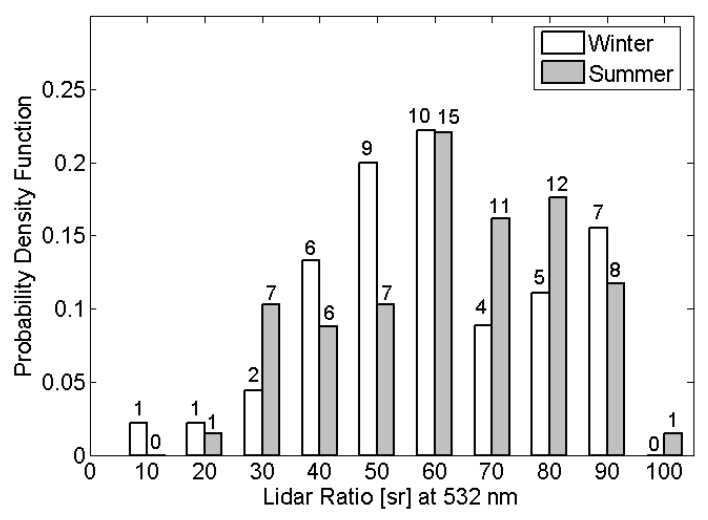

(b)

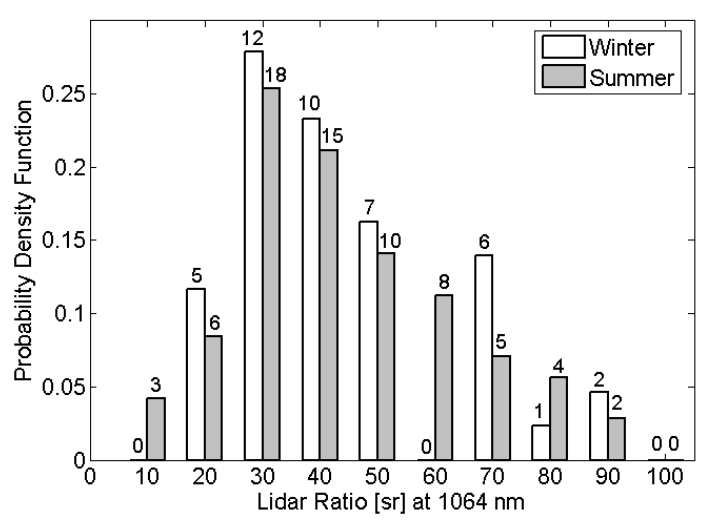

(c)

Fig. 4. Lidar-derived daytime lidar ratio: (a) Annual cycle; probability density functions at (b) 532 and (c) $1064 \mathrm{~nm}$. The numbers above the bars indicate the number of observation days.

colour index), AE (hereinafter called Ångström exponent). For each lidar profile a profile of Ångström exponent values, $\operatorname{AE}(z)$, is calculated as:

$\mathrm{AE}(z)=-\frac{\ln \left[\frac{\beta\left(\lambda_{1}, z\right)}{\beta\left(\lambda_{2}, z\right)}\right]}{\ln \left[\frac{\lambda_{1}}{\lambda_{2}}\right]}$ 


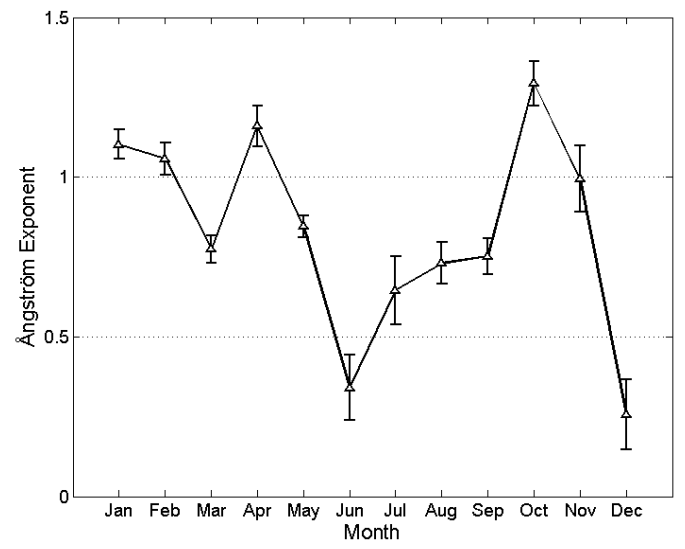

(a)

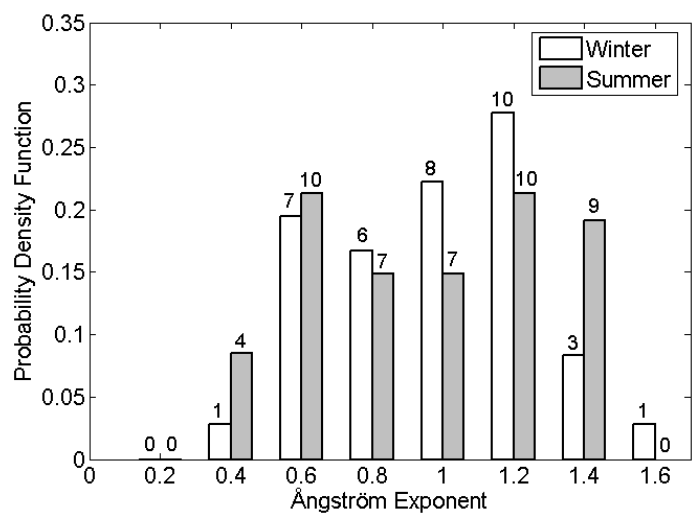

(b)

Fig. 5. Lidar-derived daytime backscatter-related Ångström exponent: (a) Annual cycle; (b) probability density function. The numbers above the bars indicate the number of observation days.

where $\lambda_{1}$ and $\lambda_{2}$ are the wavelengths of 532 and $1064 \mathrm{~nm}$, respectively. For each profile a single value of AE was obtained by calculating the arithmetic mean of all $\operatorname{AE}(z)$ in the profile only in the regions containing aerosols (i.e. where both $\beta\left(\lambda_{1}, z\right)$ and $\beta\left(\lambda_{2}, z\right)$ are different from zero). The errorbar associated to each single $\mathrm{AE}$ value was computed as the standard deviation. In Figure 5a the monthly mean estimates and their mean errorbar were computed from the single values of $\mathrm{AE}$ with the ML estimation (Eqs. A1 and A2, respectively). The Ångström exponent stays between 0.25 and 1.3 over the whole year. Its mean value is found at $1.0 \pm 0.02$ and $0.82 \pm 0.02$ in winter and summer, respectively. Saharan dust particles which usually have a small AE ranging between 0 and 0.5 are the main contributor of the $\mathrm{AE}$ decrease observed between winter and summer. A peak around 1.15 is detected in April (in Fig. 4a the lidar ratio also reached a peak during that month). In a study led by Montserrat (1998) about the relation between synoptic patterns and wildfire outbreaks in Catalonia over a period of 12 years the author found a secondary peak of wildfires in April (the first peak being in July) that was attributed to late spring rains and the vegetation dryness at this period of the

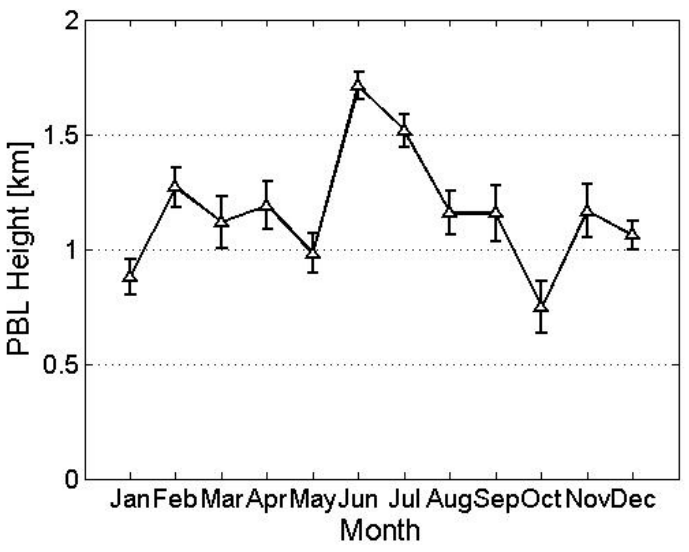

(a)

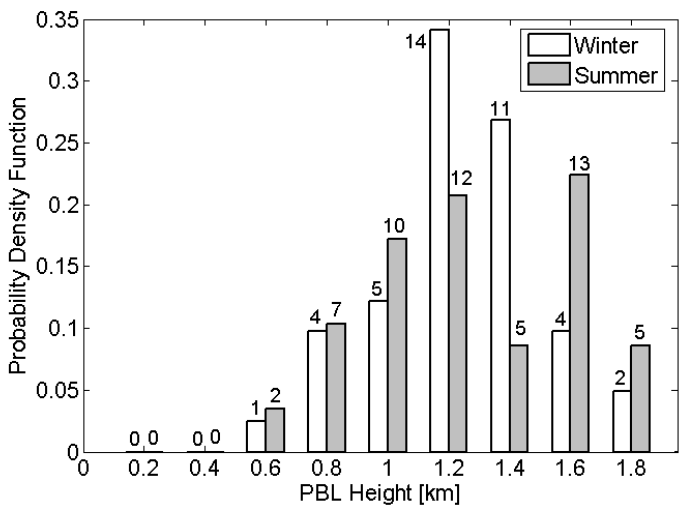

(b)

Fig. 6. Lidar-derived daytime PBL height: (a) Annual cycle; (b) probability density function. The numbers above the bars indicate the number of observation days.

year due to phenomenal and climate reasons. The last decade has been the hottest ever recorded in Northeastern Spain and it is very likely that Montserrat's (1998) hypothesis might still be true for the period studied here (2007-2009). Under this hypothesis small particles from spring wildfires in Catalonia might possibly explain the increase in the Ångström exponent in April. From Fig. 5b the Ångström exponent has a similar PDF distribution for both seasons where two main peaks occur at $0.5-0.6$ and at 1.0-1.2. If we exclude the month of December (see Sect. 3.1), the lowest Ångström exponent values are reached in June and July when Saharan dust intrusions are more frequent. The August monthly mean is not as low probably because of the influence of particles originating from forest fires, most of them occurring during that month.

Figure 6 shows the annual cycle and the PDF of the PBL height. The errorbar of each single value of the PBL height was computed as the standard deviation of all the PBL heights retrieved for each measurement (Sicard et al., 2006). In Fig. 6a the monthly mean estimates and their mean errorbar were computed with the ML estimation (Eqs. A1 and A2, respectively). The mean PBL height reaches $1035 \pm 44 \mathrm{~m}$ 
in winter and $1388 \pm 33 \mathrm{~m}$ in summer. In winter it varies between 400 and $1770 \mathrm{~m}$ and in summer between 500 and $1910 \mathrm{~m}$. The cases where the PBL height is found above $1800 \mathrm{~m}$ are very seldom. Except for a jump in June and July (Fig. 6a) relatively small differences are observed between summer and winter. This has also been observed in other coastal regions (Matthias et al., 2004). A similar climatology made earlier by Sicard et al. (2006) and based on measurements performed during the period of maximum insulation between 10:00 and 15:00 UTC and over a period of almost three years explained thanks to previous works from Millán et al. $(1992,1997)$ that "the limited growth of the PBL in summer is partly caused by the amplified compensatory subsidence over the Mediterranean sea and its coastal areas, attributable to the combined sea breeze and upslope flows plus the formation of the Iberian thermal low over the central plateau". According to Fig. $6 \mathrm{~b} \operatorname{PDF}\left(h_{\mathrm{PBL}}<1200 \mathrm{~m}\right) \simeq 0.6$ in winter and $\operatorname{PDF}\left(h_{\mathrm{PBL}}<1400 \mathrm{~m}\right) \simeq 0.6$ in summer. These relatively small values of the PBL height indicate that, opposite to other continental cities where the PBL height follows a clear annual cycle with mean heights as high as $2500 \mathrm{~m}$ (Matthias and Bösenberg, 2002), the atmospheric stratification in Barcelona prevents the vertical development of the PBL as explained earlier by Sicard et al. (2006). We believe that the increase of the PBL height in June and July is partially due to one main factor: the strong solar radiation reaching the surface between June and August. This factor has two opposite effects: (i) the growing of the convective PBL because of the increase of the turbulence flux at the surface which is related to the soil-air temperature difference and (ii) the decrease of the convective PBL because of the amplification of the Iberian thermal low which prevents its vertical development.

\subsection{Vertical lidar profiles}

Mean extinction, backscatter and lidar ratio profiles at $532 \mathrm{~nm}$ have been obtained for winter and summer by applying the Raman algorithm to all nighttime measurements when the Raman channel was available. Since too few Saharan dust events were observed during nighttime, they were discarded from the average computation and are treated in the next Section. Figure 7 shows the winter and summer mean profiles of those parameters. Let's recall that those mean profiles are the average of a certain number of individual profiles uncorrelated one with another: some profiles may contain aerosols only in the PBL and others may contain several aerosol layers above the PBL. Because of the Raman algorithm procedure itself the individual profiles do not start and do not end at the same heights, neither the interval slicing nor the inversion spatial resolutions are the same. In order to cope with both start and stop height differences, all profiles were considered starting from the mean PBL height of its corresponding season and in case they stop before reaching the stop height they were extended using zero as filling
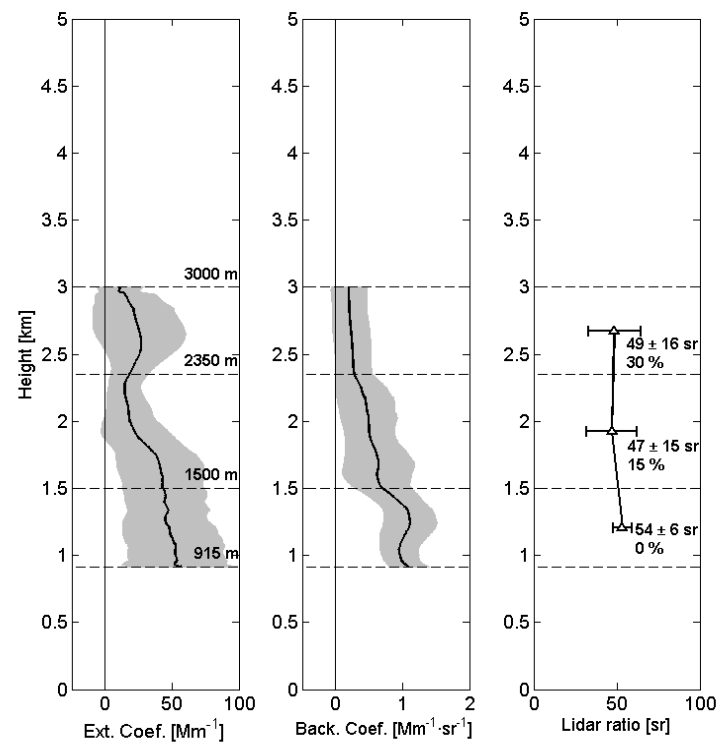

(a)
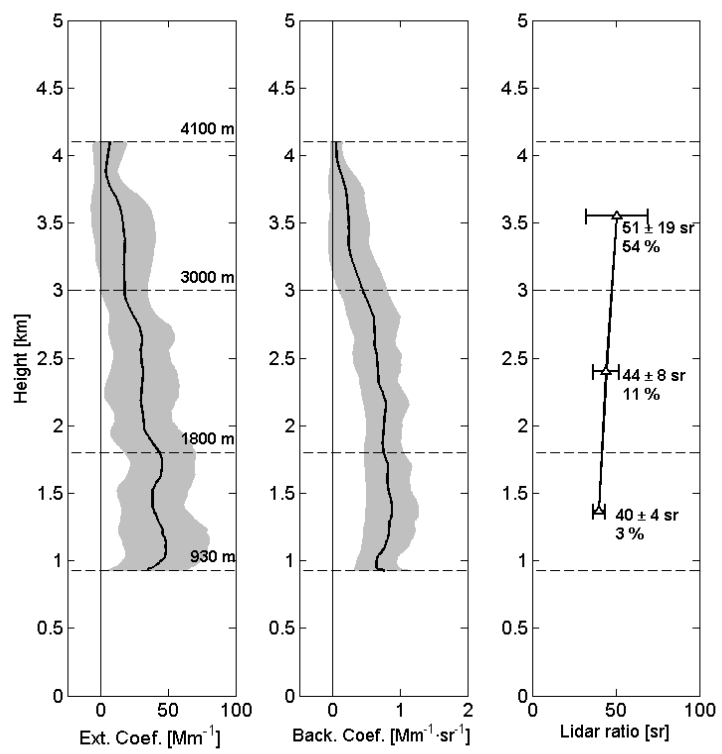

(b)

Fig. 7. (a) Winter and (b) summer mean profiles of the extinction coefficient, backscatter coefficient and lidar ratio at $532 \mathrm{~nm}$ retrieved from the nighttime measurements. Saharan dust measurements were excluded from this analysis. The grey envelope represents the standard deviation estimation (Eq. A3) associated to each range cell of the extinction and backscatter profiles. The fraction of time aerosols are not present (i.e. the aerosol extinction or backscatter coefficients are zero) is indicated for the three height intervals in the lidar ratio plot.

values. This choice of the start height ensures that all profiles contribute to the computation of the mean and also that the possible effects of an incomplete overlap factor on the extinction retrieval are avoided. 
In the computation of the mean profiles of extinction and backscatter coefficients some acceptation criteria were applied on both coefficients:

- the coefficient must be positive or equal to zero within its errorbars,

- for $\alpha>10 \mathrm{Mm}^{-1}$ and $\beta>0.2 \mathrm{Mm}^{-1} \mathrm{sr}^{-1}$, the associated errorbar must not be higher than $100 \%$,

- for $0 \leq \alpha \leq 10 \mathrm{Mm}^{-1}$ and $0 \leq \beta \leq 0.2 \mathrm{Mm}^{-1} \mathrm{sr}^{-1}$, the associated errorbar must not be higher than $10 \mathrm{Mm}^{-1}$ and $0.2 \mathrm{Mm}^{-1} \mathrm{sr}^{-1}$, respectively,

- punctually the coefficient can not reach extremely high values compared to the rest of the profile.

The points where those criteria were not fulfilled were excluded from the average computation (equivalent to force $1 / \sigma_{i}^{2}$ in Eq. (A1) to zero). At each range cell the mean extinction and backscatter coefficients were calculated as the ML estimate (Eq. A1). The errorbar associated to each range cell of the extinction and backscatter profiles (visible as a grey envelope) was computed as the standard deviation estimation (Eq. A3) and therefore is representative of the atmospheric variability. For the sake of clarity the standard error on the ML estimate, $\sigma_{\hat{\mu}}(z)$ (Eq. A2), and the standard error on the standard deviation estimate, $\sigma_{\hat{\sigma}}(z)$ (Eq. A4), are not included in Fig. 7.

Because of the extremely large variability of the lidar ratio profile retrieved with the Raman algorithm, mean values of it are given in different range intervals. Those range intervals (horizontal dashed lines in Fig. 7) were selected by looking at abrupt changes in the backscatter coefficient profiles. In each range interval the mean lidar ratio and its associated errorbars were also calculated as the ML estimate (Eq. A1) and the standard deviation estimation (Eq. A3), respectively. Here again some acceptation criteria were applied:

- the lidar ratio is excluded when the extinction or the backscatter are zero (absence of aerosols),

- punctually the lidar ratio can not reach extremely high values compared to the rest of the profile.

The fraction of time aerosols are not present has been indicated for the three range intervals in the lidar ratio plot of Fig. 7. It corresponds to the percentage of occurrences when the extinction or the backscatter coefficients are zero (indicating the absence of aerosols). Although not strictly necessary for this section because the start height was chosen high enough in order to avoid the effect of an incomplete overlap factor, the error in the extinction retrieval due to an incomplete overlap factor has been estimated in Appendix B. It results that the overlap factor error negatively biases the inverted extinction making it lower than its true value. Since the optical alignment of the system is performed several times each year the overlap factor can slightly vary from one alignment to another which prevents to make a systematic correction of it.

In relation to Fig. 7, the mean and the maximum PBL heights are, respectively, 915 and $1220 \mathrm{~m}$ in winter and 930 and $1610 \mathrm{~m}$ in summer. The layers at $915-1500 \mathrm{~m}$ in winter and at $930-1800 \mathrm{~m}$ in summer are representative of a mixture of PBL and free tropospheric aerosols. All layers above them are formed by free tropospheric aerosols only. In general extinction and backscatter coefficients are higher in summer than in winter. In winter very few aerosols are present above $2500 \mathrm{~m}$ and in summer the free troposphere is reached at approximately $4000 \mathrm{~m}$. Because of this reason the mean profiles were truncated at 3000 and $4100 \mathrm{~m}$ in winter and summer, respectively.

The lidar ratio profiles from both seasons oscillate in the same interval of values between 40 and $54 \mathrm{sr}$. During both seasons differences are observed between the lowermost layers and the free tropospheric layers above. Lidar ratio values are quite dependent on chemical and morphological aerosol properties and, accordingly, Fig. 7 indicates that the airmasses in the lowermost layers are on average different than those in the above layers. The winter layer between 915 $1500 \mathrm{~m}$ shows higher lidar ratios of $54 \mathrm{sr}$. Though further investigation is needed to explain these values a tentative explanation is given next. According to a cluster analysis of backtrajectories arriving in Barcelona performed by Jorba et al. (2004) approximately $66 \%$ of the transport pattern arriving at $1500 \mathrm{~m}$ in winter comes from the North-West quadrant. In more detail, approximately $20 \%$ comes from Northerly flows (North Europe) and $12 \%$ from fast Westerly flows (North America), which in total represents one third of the occurrences. Under this situation aerosols from urban and industrial origin (from North Europe and/or North America) could be present in Barcelona in winter in the layers between 915-1930 $\mathrm{m}$ and could explain the significant increase observed in the lidar ratio. The situation in summer when recirculation flows predominate is completely different and do not allow the transport of urban and industrial aerosols originating from North Europe and/or North America in the layer centered around $1500 \mathrm{~m}$. Additionally in summer recirculation layers, much stronger and more frequent than in winter, make the atmosphere more homogeneous (Millán et al., 1997; Rodríguez et al., 2001) and this partially explains why the peak seen in winter between $915-1500 \mathrm{~m}$ is not visible in summer in the region $930-1800 \mathrm{~m}$. In summer the lidar ratio increases slowly from 40 to $51 \mathrm{sr}$ between 930 and $4100 \mathrm{~m}$ while in winter it is around $48 \mathrm{sr}$ in the range 1500 $3000 \mathrm{~m}$. Note that in summer the lidar ratio errorbar in the lowermost range is higher than in winter. This is due to a larger variety of aerosol types present in the PBL in summer. The summer anticyclonic situation favors weather stability which leads to a greater accumulation of aerosols in the lowest layer (confinement of air-masses and less frequent wet scavenging). This effect is reinforced by the strong temperature inversion between the PBL and the recirculation layer 
above which acts as a lid and prevents vertical mixing ( $\mathrm{Lu}$ and Turco, 1994). Finally it is worth noting that since Saharan dust measurements were excluded in this analysis the winter and summer mean lidar ratio profiles shown here are lower than the mean values found in the seasonal variability study (Sect. 3.2). While in the two lowermost layers aerosols are present more than $85 \%$ of the time in winter and summer (915-2350 and 930-3000 m, respectively), it is worth noting that in the uppermost layers (2350-3000 and 3000$4100 \mathrm{~m}$, respectively) the fraction of time aerosols are not present reaches $30 \%$ in winter and $54 \%$ in summer.

During nighttime the aerosol layers between $930-3000 \mathrm{~m}$ in summer are typically residual layers or recirculation layers due to the sea-breeze phenomenon (Millán et al., 1997). Based on aircraft measurements made in summer, Millán et al. (1997) stated that the recirculation layers, so called midlayers, mix at night with the residual layer and reach heights of $\sim 3000 \mathrm{~m}$ which is in total agreement with the numbers found in our study. The mean lidar ratio in this layer is 40 $44 \mathrm{sr}$ in summer.

\subsection{Special events}

Special events in Barcelona are made of Saharan dust intrusions almost all year round and summer forest fires mostly in August. The first type of event is much more frequent and predictable than the second one and in the framework of EARLINET special measurements are performed for dust intrusions. In order to look at the effect of both events on the aerosol optical properties obtained in Barcelona, a case study including both types of aerosols is presented. The measurements were performed on 6 August 2008 between 01:42-04:11 UTC (150 min, nighttime) and 18:2418:53 UTC (30 min, daytime). The nighttime measurement was inverted with both the Raman and the two-component elastic lidar algorithm constrained with the sun-photometer AOT interpolated between the last and the first AOT measurement available. The last sun-photometer AOT measured on 5 August 2008 (at 17:19 UTC) was 0.29 at $532 \mathrm{~nm}$, while the first AOT measured on 6 August 2008 (at 06:09 UTC) was 0.18 . The general tendency of the AOT on 6 August follows a very slight decrease along the day. A simple linear interpolation gives an AOT value at 01:42 UTC of 0.22 at $532 \mathrm{~nm}$. This value was used to constrain the nighttime lidar inversion. The daytime measurement at 18:2418:53 UTC was inverted with the two-component elastic lidar algorithm constrained with the sun-photometer AOT. Results are presented in Plate 1. Plate 1a shows the time evolution of the range-square-corrected signal at $532 \mathrm{~nm}$ as a function of height. Three layers are visible in both measurements: the PBL below $600 \mathrm{~m}$, a first aerosol layer below $2000 \mathrm{~m}$ and a second thicker layer which extends up to $5800 \mathrm{~m}$ at 01:42 UTC and up to $4000 \mathrm{~m}$ at 18:24 UTC. One sees that the downward motion of the highest layer between 01:42 and 18:24 UTC, which might be due to subsidence ef- fects, is associated with a decrease of the AOT at $532 \mathrm{~nm}$ from 0.22 down to 0.17 . This probably reveals either an effect of aerosol sedimentation or a reduction of the intrusion intensity.

Plate $1 \mathrm{~b}$ shows the profiles of backscatter and extinction coefficients, as well as the backscatter-derived Ångström exponent at 01:42 and 18:24 UTC. The lidar ratio retrieved by means of the Raman algorithm at 01:42 UTC is also shown as well as its mean value (calculated as the ML estimate (Eq. A1) in the layers $930-2000 \mathrm{~m}$ and $2000-5000 \mathrm{~m}$. The errorbar associated to each mean value was calculated as the standard deviation (Eq. A3). Negative extinctions (due to noise propagation) retrieved by the Raman algorithm are not represented. The "false" increase of the Raman-derived extinction coefficient below $1000 \mathrm{~m}$ is due to the overlap factor error (see Appendix B). For the computation of the lidar ratio mean values the points with a value greater than $100 \mathrm{sr}$ or with an errorbar larger than the value itself, i.e. greater than $100 \%$, were rejected as "outliers". During both measurements large extinction values $\left(>50 \mathrm{Mm}^{-1}\right)$ are reached in the upper layer. The Raman-inverted extinction profile (at 01:42 UTC) indicates that values exceeding $50 \mathrm{Mm}^{-1}$ are also reached in the region 930-2000 m. At 18:24 UTC such high values are not reached. By looking at the extinction and backscatter profiles, it appears clearly that the center of mass of the upper layer slightly decreases between 01:42 and 18:24 UTC while the top of the layer decreases significantly from 5800 down to $4000 \mathrm{~m}$. The backscatter profiles from 01:42 UTC show that the profile retrieved with the two-component elastic lidar algorithm exactly follows the Raman-retrieved profile and that it is always within the errorbar interval (grey envelope) of the latter. The Ramanretrieved lidar ratio shows a large variability with rather large values (in two regions it equals or exceeds $100 \mathrm{sr}$ ). In the 930-2000 m region its mean value is $52 \pm 18 \mathrm{sr}$ and in the upper layer it is $46 \pm 26 \mathrm{sr}$. Over the whole atmospheric column those numbers are in good agreement with the value of $52 \mathrm{sr}$ retrieved by the two-component elastic lidar algorithm. At 18:24 UTC this value slightly decreases down to $50 \mathrm{sr}$. Though it is not shown in Plate $1 \mathrm{~b}$ for the sake of graphical clarity, it is interesting to have a look at the lidar ratio values retrieved at $1064 \mathrm{~nm}$, which are 50 sr at 01:42 UTC and $44 \mathrm{sr}$ at 18:24 UTC. One sees clearly the predominance of Saharan dust at 01:42 UTC where the lidar ratio is wavelengthindependent. At 18:24 UTC the difference has increased between both wavelengths indicating a lesser influence of Saharan dust on the columnar value. Recently Tesche et al. (2009) published a rather complete list of references about desert dust lidar ratio observations by Raman lidar. In summary desert dust lidar ratio values between 50 and $70 \mathrm{sr}$ have been observed in the last 6 years. In the following paragraphs we will focus on both layers $930-2000 \mathrm{~m}$ and $2000-5000 \mathrm{~m}$.

Plate $1 \mathrm{c}$ and $\mathrm{d}$ are HYSPLIT (the Hybrid Single Particle Lagrangian Integrated Trajectory Model) (Draxler and Rolph, 2003; Rolph, 2003) backtrajectories provided by 

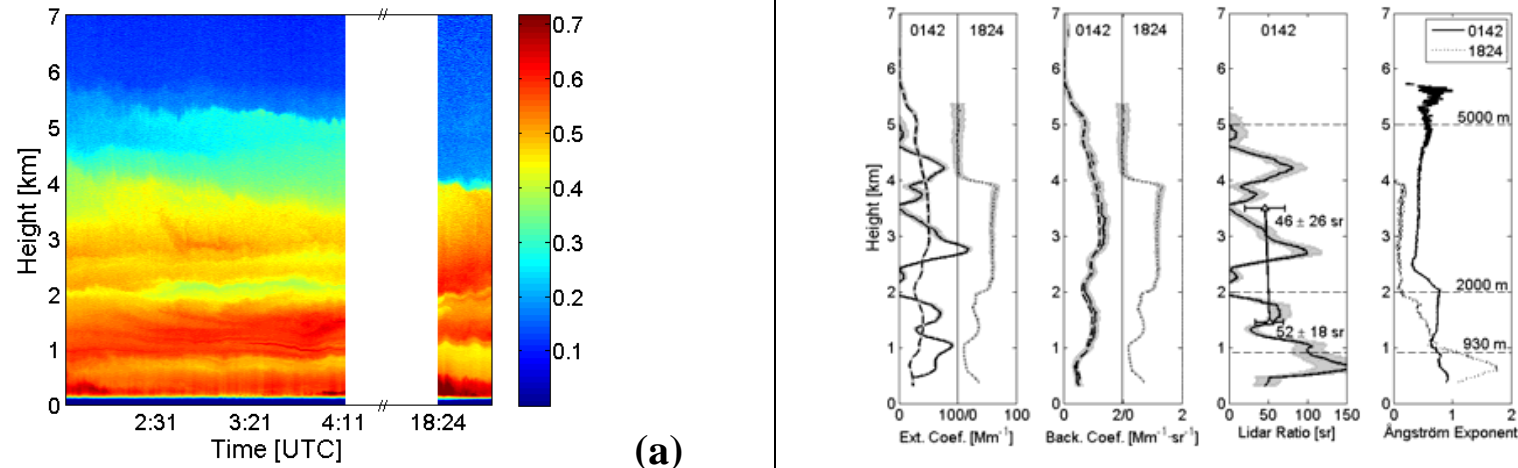

(b)
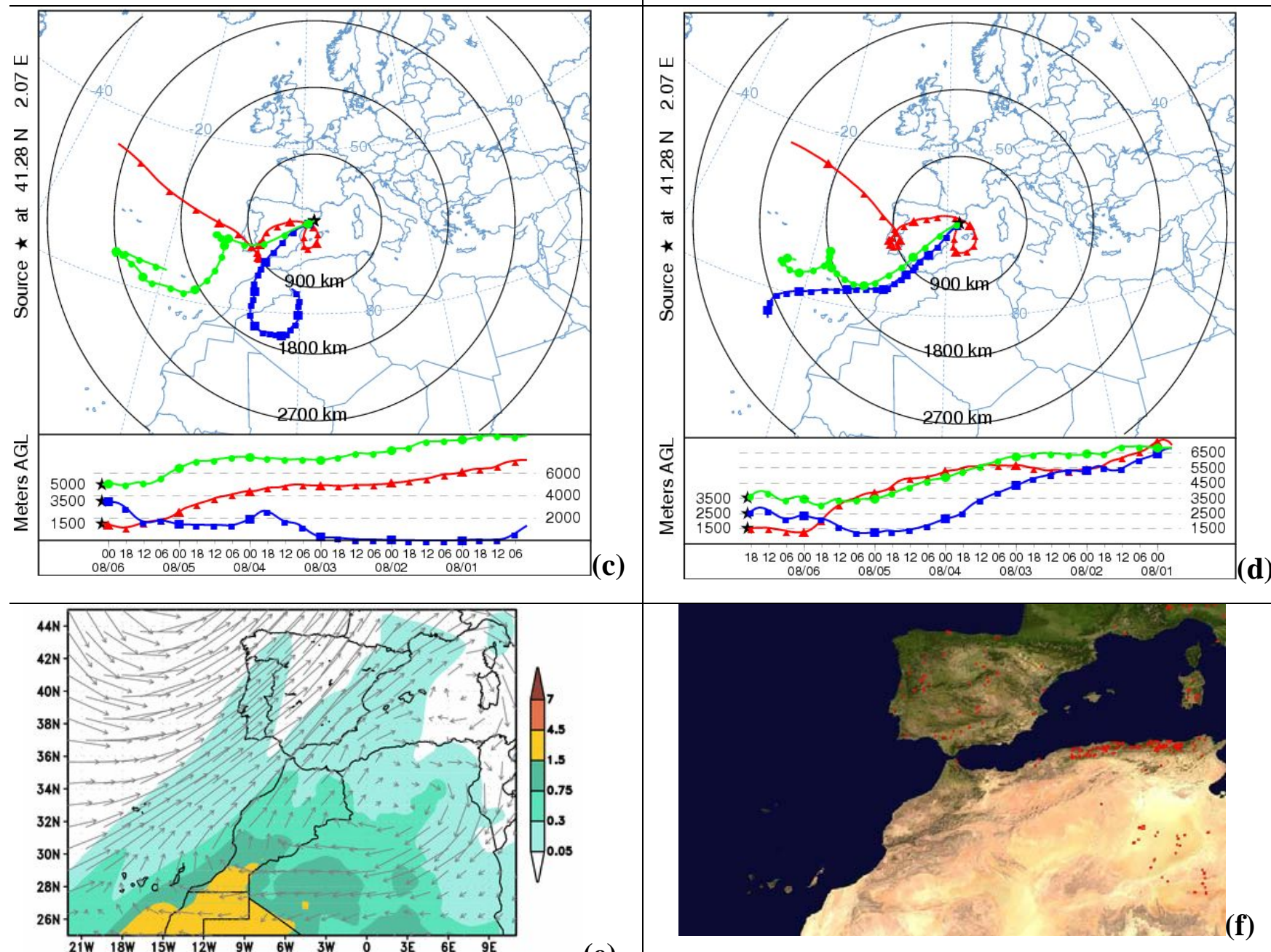

(e)

Plate 1 Measurements performed on 6 August 2008 at 01:42 and 18:24 UTC. (a) Range-square-corrected signal at $532 \mathrm{~nm}$ (the numbers in white in the image indicate the sun-photometer AOT); (b) Extinction and backscatter coefficients (solid line: Raman inversion at 01:42 UTC, dashed line: AOT-constrained two-component elastic lidar algorithm at 01:42 UTC (LR=52 sr), dotted line: AOT-constrained two-component elastic lidar algorithm ( $L R=50 \mathrm{sr}$ ) at 18:24 UTC), lidar ratio (Raman inversion at 01:42 UTC) and backscatter-related Ångström Exponent; (c) Hysplit backtrajectories arriving at Barcelona on 6 August 2008 at 02:00 UTC and (d) at 19:00 UTC; (e) BSCDREAM8b dust optical thickness at $550 \mathrm{~nm}$ and wind at $3000 \mathrm{~m}$ on 6 August 2008 at 12:00 UTC; (f) MODIS map of fires started between 29 July and 7 August 2008. 
NOAA - ARL (National Oceanic and Atmospheric Administration - Air Resources Laboratory) and used to check the air-masses origin. The blue trajectories show that in both cases the air-mass came from North Africa and that it travelled as low as at ground level before reaching Barcelona. This clearly identifies the plume seen at 2000 $5800 \mathrm{~m}$ at $01: 42$ UTC and that at $2000-4000 \mathrm{~m}$ at $18: 24$ UTC as aerosols from desert origin. The presence of Saharan dust above Barcelona is also confirmed by the BSC-DREAM8b map of dust optical thickness (Plate 1e) which predicted the presence of dust particles above Barcelona with AOTs as high as 0.3 at $550 \mathrm{~nm}$ at 12:00 UTC.

The backscatter-retrieved Ångström exponent is quite low and constant above $2000 \mathrm{~m}$ in both cases: its mean value is 0.46 at 01:42 UTC and 0.11 at 18:24 UTC. As said before, this is a typical signature of mineral dust as low values of $\mathrm{AE}$ are representatives of aerosols with wavelength-independent optical properties. In the North Africa source region Müller et al. (2009) measured mean Ångström exponent values of 0.5 for Saharan dust. Though further investigation is needed to explain the AE difference between the measurement at 01:42 UTC and that at 18:24 UTC some explanations such as dust aging are suggested. The column-averaged size distribution retrieved from the sun-photometer measurements (not shown here) shows in the morning of 6 August 2008 a displacement of the coarse mode towards larger particles from 2.24 to $3.86 \mu \mathrm{m}$ at the same volume size distribution of $0.063 \mu \mathrm{m}^{3} \mu \mathrm{m}^{-2}$. If this increase was due to the enlargement of the dust particles in the layer above $2000 \mathrm{~m}$, e.g. due to coagulation with other aerosols or due to cloud processing (clouds were present between 7 and $9 \mathrm{~km}$ at 18:24 UTC) (Sokolik, 1998), then the Ångström exponent in this layer would decrease accordingly.

In the bottom layer 930-2000 $\mathrm{m}$ higher values of the lidar ratio are found (the mean LR is $52 \mathrm{sr}$ and peaks greater than $100 \mathrm{sr}$ are reached) at 01:42 UTC. They are associated with also higher values of the Ångström exponent (the mean $\mathrm{AE}$ is 0.73). At 18:24 UTC the AE also increases to a mean value of 0.53 . This unusual change of lidar ratio and Ångström exponent is due to the presence of a different type of aerosol. The red trajectories (Plate $1 \mathrm{c}$ and d) show that in both cases the air-mass arriving at $1500 \mathrm{~m}$ has a peninsular origin. The MODIS (Moderate Resolution Imaging Spectroradiometer) global map of fires started between 29 July and 7 August 2008 (Plate 1f) clearly shows a quite large number of active fires over the Iberian Peninsula, mostly in East and Northeast Portugal and in Central and South Spain. The large lidar ratios and Ångström exponents found in the 930$2000 \mathrm{~m}$ region are the signature of high absorbing and small particles such as biomass-burning particles produced by forest fires. Wandinger et al. (2002) found values of biomassburning aerosols at $532 \mathrm{~nm}$ between 40 and $80 \mathrm{sr}$ while Balis et al. (2003) found a rather constant value around $61 \mathrm{sr}$ at $355 \mathrm{~nm}$ and an Ångström exponent around 1.8. Since the profiles of both the lidar ratio and the Ångström exponent present a large variability we suspect that the aerosols observed in the 930-2000 m region might be due to a mixing of Saharan dust and biomass-burning and possibly recirculation polluted air-masses.

\section{Conclusions}

For the first time the seasonal variability of aerosol optical properties has been studied by means of a Raman lidar in northeastern Spain. The discussion based on the annual and seasonal cycles of the AOT, the lidar ratio, the Anngström exponent and the PBL height as well as on the seasonal mean profiles of the aerosol optical coefficients allowed to show the impact of most of the natural events (Saharan dust intrusions, wildfires, etc.) and meteorological situations (summer anticyclonic situation, the formation of the Iberian thermal low, winter long-range transport from North Europe and/or North America, re-circulation flows, etc.) occurring in the Barcelona area.

The lidar-derived winter and summer mean AOT are $0.10 \pm 0.03$ and $0.20 \pm 0.03$ at $532 \mathrm{~nm}$ and $0.05 \pm 0.01$ and $0.09 \pm 0.02$ at $1064 \mathrm{~nm}$. The PBL AOT is also virtually constant over the year which indicates that PBL and troposphere are clearly decoupled. Its annual mean is around $0.08 \pm 0.01$ at $532 \mathrm{~nm}$ and around $0.03 \pm 0.01$ at $1064 \mathrm{~nm}$, which represents 57 and $43 \%$ of the annual mean columnar AOT, respectively. During summer the impact of long-range transport of aerosols reduces the fraction of AOT contained in the PBL to $35 \%$.

While the mean lidar ratio values increase between winter and summer of about $10 \mathrm{sr}$ (from 51 to $60 \mathrm{sr}$ at $532 \mathrm{~nm}$ and from 33 to $42 \mathrm{sr}$ at $1064 \mathrm{~nm}$ ), the Ångström exponent decreases (which indicates an increase of the size of the particles) from 1 in winter to 0.8 in summer. Except for the months of June and July the PBL height annual cycle did not show a clear difference between winter and summer. Vertical profiles retrieved by means of the Raman algorithm revealed summertime recirculation layers with a mean lidar ratio of 40-44 sr between the PBL and up to approximately $3000 \mathrm{~m}$.

A special event of Saharan dust and biomass burning particles observed in August 2008 has been analyzed in detail. The combined analysis of nighttime Raman- and daytime pure elastic-inversions appeared to be suited for discriminating spatially different types of aerosols and for following their spatial and temporal evolution.

In conclusion we believe our results contribute to increase our knowledge of the aerosol optical properties over Northeastern Spain first, in terms of vertical distribution thanks to the lidar principle and second, temporally thanks to the climatology presented. Even though the annual cycles of all the parameters studied in the paper have allowed identifying on a statistical basis the natural events and the meteorological situations affecting the Barcelona area, the probability density functions have clearly shown a large dispersion. It is hoped 
that the results presented here will allow enhancing global aerosol models and radiative transfer models through a more accurate knowledge of the optical properties of the Western Mediterranean aerosols.

\section{Appendix A}

The maximum likelihood estimation (Barlow, 1989) of a set of $N$ measurements $x=\left[x_{1}, x_{2}, \ldots, x_{i}, \ldots, x_{N}\right]$ known with an error $\sigma=\left[\sigma_{1}, \sigma_{2}, \ldots, \sigma_{i}, \ldots, \sigma_{N}\right]$ is formed by the weighted average, $\bar{x}$, and estimated by $\hat{\mu}$ as indicated in Eq. (A1) in the table below. Likewise, the standard error associated to $\hat{\mu}, \sigma_{\hat{\mu}}$, is given by Eq. (A2).

The unweighted unbiased (Bessel's $N-1$ "population"correction) standard deviation estimation of $\hat{\mu}, \hat{\sigma}$, is given by Eq. (A3). The error associated to $\hat{\sigma}, \sigma_{\hat{\sigma}}$, is given in Eq. (A4). In the latter equation $\sigma$ is the true standard deviation. In general substituting $\sigma$ by $\hat{\sigma}$ gives a standard error reasonably close to the truth.

\begin{tabular}{lll}
\hline & Estimate & $\begin{array}{l}\text { Standard error on } \\
\text { the estimate }\end{array}$ \\
\hline ML estimation (weighted) & $\hat{\mu}=\bar{x}=\frac{\sum_{i=1}^{N} \frac{x_{i}}{\sum_{i=1}^{N} \frac{1}{\sigma_{i}^{2}}}}{i^{N}} \quad$ (A1) & $\sigma_{\hat{\mu}}=\frac{1}{\sqrt{\sum_{i=1}^{N} \frac{1}{\sigma_{i}^{2}}}} \quad$ (A2) \\
\hline $\begin{array}{l}\text { Standard deviation estimation } \\
\text { (unweighted unbiased) }\end{array}$ & $\hat{\sigma}=\sqrt{\frac{1}{N-1} \sum_{i=1}^{N}\left(x_{i}-\hat{\mu}\right)^{2}} \quad$ (A3) $\quad \sigma_{\hat{\sigma}}=\frac{\sigma}{\sqrt{2(N-1)}} \quad$ (A4)
\end{tabular}

\section{Appendix B}

The aerosol extinction coefficient inverted by the Raman lidar inversion algorithm (Ansmann et al., 1992) is directly related to the derivative of the so-called S-curve (i.e., the logarithm of the ratio between the nitrogen molecular number density profile, $N_{R}(R)$, and the range-corrected Raman signal, $R^{2} P_{\lambda_{R}}(R)$ ). Following Chap. 6, Sect. 6.2 in Reba (2010b) when the Raman return signal is subject to the effects of an incomplete overlap factor the inverted aerosol extinction becomes:

$$
\begin{aligned}
\alpha_{\lambda_{0}}^{\mathrm{aer}}(R) & =\frac{\frac{d}{d R}\left[\ln \frac{N_{R}(R)}{R^{2} P_{\lambda_{R}}(R) \xi(R)}\right]-f(R)}{g(R)} \\
& =\underbrace{\frac{\frac{d}{d R}\left[\ln \frac{N_{R}(R)}{R^{2} P_{\lambda_{R}}(R)}\right]-f(R)}{g(R)}}_{\text {ideal term }}-\underbrace{-\frac{\xi^{\prime}(R)}{g(R)}}_{\text {error term }},
\end{aligned}
$$

where $f(R)=\alpha_{\lambda_{0}}^{\mathrm{mol}}(R)+\alpha_{\lambda_{R}}^{\mathrm{mol}}(R)$ assimilates the atmospheric molecular contributions at the elastic and Raman wavelengths, $\lambda_{0}$ and $\lambda_{R}$, respectively, $\xi(R)$ represents the overlap factor and $g(R)=1+\left(\frac{\lambda_{0}}{\lambda_{R}}\right)^{\kappa}$ ( $\kappa$ expressing the $\lambda^{-\kappa}$ dependency of the aerosol extinction coefficient) is an auxiliary function.
Next, and as an example, we assume $\kappa=1$ (Ansmann et al., 1992), $\lambda_{0}=532 \mathrm{~nm}, \lambda_{R}=607 \mathrm{~nm}$ and that the overlap factor approaches unity (i.e., the full overlap condition) following a linear approximation defined by $\xi\left(R_{1}\right)=0.95$ at $R_{1}=590 \mathrm{~m}$ and $\xi\left(R_{2}\right)=1$ at $R_{1}=915 \mathrm{~m}$ (these figures being tentative values for the overlap factor of the UPC lidar system). Under these conditions, the error term defined in Eq. (A5) contributes to the inverted extinction a systematic error of $\varepsilon\left(R_{1}\right)=-87 \mathrm{Mm}^{-1}$ and $\varepsilon\left(R_{2}\right)=-82 \mathrm{Mm}^{-1}$. As a result the inverted extinction becomes negatively biased by the overlap factor error which makes the inverted extinction lower than its true value.

Acknowledgements. This work is supported by the European Union under the project EARLINET-ASOS (EU Coordination Action, contract $\mathrm{n}^{\circ} 025991$ (RICA)); by the MICINN (Spanish Ministry of Science and Innovation) and FEDER funds under the project TEC2009-09106/TEC, and the Complementary Actions CGL200801330-E/CLI and CGL2009-08031-E/CLI; and by the European Space Agency under the project 21487/08/NL/HE. The authors gratefully acknowledge the NOAA Air Resources Laboratory (ARL) for the provision of the HYSPLIT transport and dispersion model and READY website (http://www.arl.noaa.gov/ready.html) used in this publication. Generalitat de Catalunya/AGAUR is also thanked for Mr. Md. Reba's and Mr. Kumar's pre-doctoral fellowships.

Edited by: F.-J. Lübken

\section{References}

Amiridis, V., Balis, D. S., Kazadzis, S., Bais, A., Giannakaki, E., Papayannis, A., and Zerefos, C.: Four-year aerosol observations with a Raman lidar at Thessaloniki, Greece, in the framework of European Aerosol Research Lidar Network (EARLINET), J. Geophys. Res., 110, D10203, doi:10.1029/2005JD006190, 2005.

Ansmann, A., Riebesell, M., and Weitkamp, C.: Measurement of atmospheric aerosol extinction profiles with a Raman lidar, Opt Lett., 15(13), 746-748, 1990.

Ansmann, A., Wandinger U., Riebesell M., Weitkamp C., and Michaelis, W.: Independent measurement of extinction and backscatter profiles in cirrus-clouds by using a combined Raman elastic-backscatter lidar, Appl. Opt., 31, 7113-7131, 1992.

Balis, D., Amiridis, V., Zerefos, C., Gerasopoulos, E., Andreae, M., Zanis, P., Kazantzidis, A., Kazadzis, S., and Papayannis, A.: Raman lidar and sunphotometric measurements of aerosol optical properties over Thessaloniki, Greece during a biomass burning episode, Atmos. Environ., 37, 4529-4538, 2003.

Barlow, R. J.: Statistics. A Guide to the Use of Statistical Methods in Physical Sciences, Wiley, Chichester, United Kingdom, 1989.

Beck, J. P., Kryzanowski, M., and Koffi, B.: Ozone in the European Union, in: The Consolidated Report by the European Topic Centre Air Quality, European Commission, Office for Official Publication, Bilthoven, The Netherlands, 1999.

Bösenberg, J., Ansmann, A., Baldasano, J. M., Balis, D. Böckmann, C., Calpini, B., Chaikovsky, A., Flamant, P., Hagard, A., Mitev, V., Papayannis, A., Pelon, J., Resendes, D., Schneider, J., Spinelli, N., Trickl, T., Vaughan, G., Visconti, G., and 
Wiegner, M.: EARLINET: A European aerosol research lidar network, in Proceedings of the 20th ILRC, Vichy, France, 155$158,2000$.

De Leeuw, F., Sluyter, R, van Breugel, P., and Bogman, F.: Air Pollution by ozone in Europe in 1999 and the summer of 2000, European Environmental Agency Topic Report number 1/2001, EEA, Copenhagen, Denmark, 2001.

De Tomasi, F., Blanco, A., and Perrone, M. R.: Raman lidar monitoring of extinction and backscattering of African dust layers and dust characterization, Appl. Opt., 42, 1699-1709, 2003.

Draxler, R. R. and Rolph, G. D.: NOAA Air Resources Laboratory, Silver Spring, MD, available at: http://www.arl.noaa.gov/ready/ hysplit4.html, 2003.

Estellés, V., Martínez-Lozano, J. A., Utrillas, M. P., and Campanelli, M.: Columnar aerosol properties in Valencia (Spain) byground-based Sun photometry, J. Geophys. Res., 112, D11201, doi:10.1029/2006JD008167, 2007.

Fernald, F. G.: Analysis of atmospheric lidar observations: some comments, Appl. Opt., 23, 652-653, 1984.

Holben, B. N., Eck, T. F., Slutsker, I., Tanre, D., Buis, J. P., Setzer, A., Vermote, E., Reagan, J. A., Kaufman, Y. J., Nakajima, T., Lavenu, F., Jankowiak, I., and Smirnov, A.: AERONET: A federated instrument network and data archive for aerosol characterization, Remote Sens. Environ., 66, 1-16, 1998.

Forster, P., Ramaswamy, V., Artaxo, P., Berntsen, T., Betts, R., Fahey, D. W., Haywood, J., Lean, J., Lowe, D. C., Myhre, G., Nganga, J., Prinn, R., Raga, G., Schulz, M., and Van Dorland, R.: Changes in atmospheric constituents and in radiative forcing, in Climate Change 2007, in: The Physical Science Basis. Contribution of Working Group I to the Fourth Assessment Report of the Intergovernmental Panel on Climate Change, edited by: Solomon, S., Qin, D., Manning, M., Chen, Z., Marquis, M., Averyt, K. B., Tignor, M., and Miller H. L., Cambridge Univ. Press, Cambridge, United Kingdom, 129-234, 2007.

Jiménez, P., Lelieveld, J., and Baldasano, J. M.: Multiscale modeling of air pollutants dynamics in the northwestern Mediterranean basin during a typical summertime episode, J. Geophys. Res., 111, D18306, doi:10.1029/2005JD006516, 2006.

Jorba, O., Pérez, C., Rocadenbosch, F., and Baldasano, J. M.: Cluster Analysis of 4-Day Backtrajectories Arriving in the Barcelona Area (Spain) from 1997 to 2002, J. Appl. Meteorol., 43, 887901, 2004.

Kallos, G., Nickovic, S., Jovic, D., Kakaliagou, O., Papadopoulos, A., Misirlis, N., Boukas, L., Mimikou, N., Sakellaridis, G., Papageorgiou, J., Anadranistakis, E., and Manousakis, M.: The Regional Weather Forecasting System SKIRON and its capability for forecasting dust uptake and transport, in Proc. of the WMO conference on dust storms, Damascus, Syria, p. 9, 1997.

Klett, J. D.: Lidar inversion with variable backscatter/extinction ratios, Appl. Opt. 24, 1638-1643, 1985.

Landulfo, E., Papayannis, A., Artaxo, P., Castanho, A. D. A., de Freitas, A. Z., Souza, R. F., Vieira Junior, N. D., Jorge, M. P. M. P., Sánchez-Ccoyllo, O. R., and Moreira, D. S.: Synergetic measurements of aerosols over São Paulo, Brazil using LIDAR, sunphotometer and satellite data during the dry season, Atmos. Chem. Phys., 3, 1523-1539, doi:10.5194/acp-3-1523-2003, 2003.

Lu, R. and Turco, R.: Air pollutant transport in a coastal environment. PartI: Two-dimensional simulations of sea-breeze and mountains effects, J. Atmos. Sci., 51, 2285-2308, 1994.

Matthias, V. and Bösenberg, J.: Aerosol climatology for the planetary boundary layer derived from regular lidar measurements, Atmos. Res., 63, 221-245, 2002.

Matthias, V., Balis, D., Bösenberg, J., Eixmann, R., Iarlori, M., Komguem, L., Mattis, I., Papayannis, A., Pappalardo, G., Perrone, M. R., and Wang, X.: Vertical aerosol distribution over Europe: Statistical analysis of Raman lidar data from 10 European Aerosol Research Lidar Network (EARLINET) stations, J. Geophys. Res., 109, D18201, doi:10.1029/2004JD004638, 2004.

Mattis, I., Ansmann, A., Müller, D., Wandinger, U., and Althausen, D.: Multiyear aerosol observations with dualwavelength Raman lidar in the framework of EARLINET, J. Geophys. Res., 109, D13203, doi:10.1029/2004JD004600, 2004.

Mattis, I., Mona, L., Müller, D., Pappalardo, G., Alados Arboledas, L., D’Amico, G., Amodeo, A., Apituley, A., Baldasano, J. M., Böckmann, C., Bösenberg, J., Chaikovsky, A., Comeron, A., Giannakaki, E., Grigorov, I., Guerrero Rascado, J. L., Gustafsson, O., Hansen, G., Iarlori, M., Mitev, V., Molero Menéndez, F., Nicolae, D., Papayannis, A., Pérez García-Pando, C., Perrone, M. R., Pietruczuk, A., Putaud, J.-P., Ravetta, F., Rodríguez, A., Seifert, P., Sicard, M., Simeonov, V., Sobolewski, P., Spinelli, N., Stohl, A., Tesche, M., Trickl, T., Wandinger, U., and Wiegner, M.: EARLINET correlative measurements for CALIPSO, in: Lidar Technologies, Techniques, and Measurements for Atmospheric Remote Sensing III, edited by: Singh, U. N. and Pappalardo, G., Procedings SPIE, 6750, 67500Z, doi:10.1117/12.7380902007, 2007.

Millán, M. M., Artiñano, B., Alonso, L., Castro, M., FernandezPatier, R., and Goberna, J.: Meso-meteorological Cycles of Air Pollution in the Iberian Peninsula (MECAPIP). Air Pollution Research Report 44 (EUR No. 14834) CEC-DG XII/E-1 (1992) Rue de la Loi, 200, B-1040, Brussels, 1992.

Millán, M. M., Salvador R., Mantilla E., and Kallos, G.: Photooxidant dynamics in the Mediterranean basin in summer: results from European research projects, J. Geophys. Res., 102, 88118823, 1997.

Mona, L., Amodeo, A., Pandolfi, M., and Pappalardo, G.: Saharan dust intrusions in the Mediterranean area: Three years of Raman lidar measurements, J. Geophys. Res., 111, D16203, doi:10.1029/2005JD006569, 2006.

Montserrat, D.: Situaciones sinópticas relacionadas con el inicio de grandes incendios forestales en Cataluña, Nimbus, 1-2, 93-112, 1998.

Müller, D., Heinold, B., Tesche, M., Tegen, I., Althausen, D., Amiridis, V., Amodeo, A., Ansmann, A., Alados-Arboledas, L., Balis, D., Comeron, A., D’Amico, G., Gerasopoulos, E., Guerrero-Rascado, J. L., Freudenthaler, V., Giannakaki, E., Heese, B., Iarlori, M., Mamouri, R. E., Mona, L., Papayannis, A., Pappalardo, G., Perrone, R.-M., Pisani, G., Rizi, V., Sicard, M., Spinelli, N., Tafuro, A., and Wiegner, M.: EARLINET observations of the 14-22 May long-range dust transport event during SAMUM 2006: validation of results from dust transport modelling, Tellus B, 61, 325-339, 2009.

Nickovic S., Papadopoulos A., Kakaliagou O., and Kallos, G.: A model for prediction of desert dust cycle in the atmosphere, J. Geophys. Res., 106, 18113-18129, 2001.

Papayannis, A., Amiridis, V., Mona, L., Tsaknakis, G., Balis, D., Bösenberg, J., Chaikovski, A., De Tomasi, F., Grigorov, I., Mat- 
tis, I., Mitev, V., Müller, D., Nickovic, S., Pérez, C., Pietruczuk, A., Pisani, G., Ravetta, F., Rizi, V., Sicard, M., Trickl, T., Wiegner, M., Gerding, M., Mamoury, R., Di Amico, G., and Pappalardo, G.: Systematic lidar observations of Saharan dust over Europe in the frame of EARLINET (2000-2002), J. Geophys. Res., 113, D10204, doi:10.1029/2007JD009028, 2008.

Pappalardo, G., Bösenberg, J., Amodeo, A., Ansmann, A., Apituley, A., Alados Arboledas, L., Balis, D., Böckmann, C., Chaikovsky, A., Comeron, A., Freudenthaler, V., Hansen, G., Mitev, V., Nicolae, D., Papayannis, A., Perrone, M. R., Pietruczuk, A., Pujadas, M., Putaud, J.-P., Ravetta, F., Rizi, V., Simeonov, V., Spinelli, N., Stoyanov, D., Trickl, T., and Wiegner, M.: EARLINET-ASOS: European Aerosol Research Lidar Network-Advanced Sustainable Observation System, American Meteorological Society Annual Meeting, San Antonio, Texas, USA, 2007.

Pappalardo, G., Papayannis, A., Bösenberg, J., Ansmann, A., Apituley, A., Alados Arboledas, L., Balis, D., Böckmann, C., Chaikovsky, A., Comeron, A., Gustafsson, O., Hansen, G., Mitev, V., Mona, L., Nicolae, D., Perrone, M. R., Pietruczuk, A., Pujadas, M., Putaud, J.-P., Ravetta, F., Rizi, F., Simeonov, V., Spinelli, N., Stoyanov, D., Trickl, T., and Wiegner, M.: EARLINET coordinated lidar observations of Saharan dust events on continental scale, IOP Conf. Ser., Earth Environ. Sci,, 7, 1, doi:10.1088/1755-1307/7/1/012002, 2009.

Pappalardo, G., Wandinger, U., Mona, L., Hiebsch, A., Mattis, I, Amodeo, A., Ansmann, A., Seifert, P., Linné, H., Apituley, A., Alados Arboledas, L., Balis, D., Chaikovsky, A., D’Amico, G., De Tomasi, F., Freudenthaler, V., Giannakaki, E., Giunta, A., Grigorov, I., Iarlori, M., Madonna, F., Mamouri, R.-E., Nasti, L., Papayannis, A:, Pietruczuk, A., Pujadas, M., Rizi, V. Rocadenbosch, F., Russo, F., Schnell, F., Spinelli, N., Wang, X., and Wiegner, M.: EARLINET correlative measurements for CALIPSO: First intercomparison results, J. Geophys. Res., 115, D00H19, doi:10.1029/2009JD012147, 2010.

Pelon, J., Flamant, C., Chazette, P., Léon, J.-F., Tanré, D., Sicard, M., and Satheesh, S. K.: Characterization of aerosol spatial distribution and optical properties over the Indian Ocean from airborne lidar and radiometry during INDOEX'99, J. Geophys. Res., 107, 8029-8041, 2002.

Pérez, C., Nickovic, S., Baldasano, J. M., Sicard, M., Rocadenbosch, F., and Cachorro, V. E.: A long Saharan dust event over the western Mediterranean: Lidar, sun photometer observations, and regional dust modeling, J. Geophys. Res., 111, D15214, doi:10.1029/2005JD006579, 2006a.

Pérez, C., Nickovic, S., Pejanovic, G., Baldasano, J. M., and Ozsoy, E.: Interactive dust-radiation modeling: A step to improve weather forecasts, J. Geophys. Res., 111, 1-17, D16206, doi:10.1029/2005JD006717, 2006b.

Pérez, N., Pey, J., Querol, X., Alastuey, A., Lopez, J.M., and Viana, M.: Partitioning of major and trace components in $\mathrm{PM}_{10}-\mathrm{PM}_{2.5^{-}}$ $\mathrm{PM}_{1}$ at an urban site in Southern Europe, Atmos. Environ., 42, 1677-1691, 2008.

Querol, X., Rodríguez, S., Cuevas, E., Viana, M., and Alastuey, A.: Intrusiones de masas de aire africano sobre la Península Ibérica y Canarias: Mecanismos de transporte y variación estacional, $3^{\mathrm{a}}$ Asamblea Hispano Portuguesa de Geodesia y Geofísica, Valencia, 2002.

Reba, M. N. M., Rocadenbosch, F., Sicard, M., Kumar, D., and Tomás, S.: On the lidar ratio estimation from the synergy be- tween AERONET sun-photometer data and elastic lidar inversion, Proc. of the 25th International Laser Radar Conference, vol. 2, ISBN 978-5-94458-109-9, Saint-Petersburg (Rusia), 59 July 2010, 1102-1105, 2010a.

Reba, M. N. M.: Data processing and inversion interfacing the UPC elastic-Raman lidar system, $\mathrm{PhD}$ Thesis., Universitat Politècnica de Catalunya, Spain, 2010b.

Rocadenbosch, F., Sicard, M., Comerón, A., Baldasano, J. M., Rodríguez, A., Agishev, R., Muñoz, C., López, M. A., and García-Vizcaino, D.: The UPC scanning Raman lidar: an engineering overview, Proceeding of the 21st ILRC, 1, 69-70, 2002.

Rodríguez, S., Querol, X., Alastuey, A., Kallos, G., and Kakaliagou, O.: Saharan dust contributions to $\mathrm{PM}_{10}$ and TSP levels in Southern and Eastern Spain, Atmos. Environ., 35, 2433-2447, 2001.

Rodríguez, S., Querol, X., Alastuey, A., and Mantilla, E.: Origin of high summer PM10 and TSP concentrations at rural sites in Eastern Spain, Atmos, Environ., 36, 3101-3112, 2002a.

Rodríguez, S.: Sources and processes affecting levels and composition of atmospheric particulate matter in the Western Mediterranean. PhD Thesis. Universitat Politècnica de Catalunya, Spain (available at http://www.tdx.cesca.es/TDX-1217102-164843/), 2002b.

Rolph, G. D.: NOAA Air Resources Laboratory, Silver Spring, MD, available at: http://www.arl.noaa.gov/ready/hysplit4.html, 2003.

Santacesaria, V., Marenco, F., Balis, D., Papayannis, A., and Zerefos, C.: Lidar observations of the Planetary Boundary Layer above the city of Thessaloniki, Greece, Il Nuovo Cimento, 21, 585-596, 1988.

Sasano, Y. and Nakane, H.: Significance of the extinction/backscatter ratio and the boundary value term in the solution for the two-component lidar equation, Appl. Opt. 23, 11-13, 1984.

Sicard, M., Pérez, C., Rocadenbosch, F., Baldasano, J. M., and García-Vizcaino, D.: Mixed-layer depth determination in the Barcelona coastal area from regular lidar measurements: methods, results and limitations, Bound.-Lay. Meteorol., 119, 135157, 2006.

Sokolik, I. N. and Toon, O. B.: Incorporation of mineralogical composition into models of the radiative properties of mineral aerosol from UV to IR wavelengths, J. Geophys. Res., 104, 9423-9444, 1999.

Tesche, M., Ansmann, A., Müller, D., Althausen, D., Mattis, I., Heese, B., Freundenthaler, V., Wiegner, M., Esselborn, M., Pisani, G., and Knippertz, P.: Vertical profiling of Saharan dust with Raman lidars and airborne HSRL in southern Morocco during SAMUM, Tellus B, 61, 144-164, 2009.

Wandinger, U., Müller, D., Böckmann, C., Althausen, D., Matthias, V., Bösenberg, J., Weiß, V., Fiebig, M., Wendisch, M., Stohl, A., and Ansmann, A.: Optical and microphysical characterization of biomass-burning and industrial-pollution aerosols from multiwavelength lidar and aircraft measurements, J. Geophys. Res. 107(D21), 8125, doi:10.1029/2000JD000202, 2002.

Winker, D. M., Hunt, W. H., and McGill, M. J.: Initial performance assessment of CALIOP, Geophys. Res. Lett., 34, L19803, doi:10.1029/2007GL030135, 2007. 